\title{
Impaired Fear Extinction Learning and Cortico-Amygdala Circuit Abnormalities in a Common Genetic Mouse Strain
}

\author{
Kathryn Hefner, ${ }^{1 \star}$ Nigel Whittle, ${ }^{2 \star}$ Jaynann Juhasz, ${ }^{1}$ Maxine Norcross, ${ }^{1}$ Rose-Marie Karlsson, ${ }^{1}$ Lisa M. Saksida, ${ }^{3}$ \\ Timothy J. Bussey, ${ }^{3}$ Nicolas Singewald, ${ }^{2}$ and Andrew Holmes ${ }^{1}$ \\ ${ }^{1}$ Section on Behavioral Science and Genetics, Laboratory for Integrative Neuroscience, National Institute on Alcoholism and Alcohol Abuse, National \\ Institutes of Health, Rockville, Maryland 20852, ${ }^{2}$ Department of Pharmacology and Toxicology, Institute of Pharmacy and Center for Molecular Biosciences \\ Innsbruck, University of Innsbruck, A-6020 Innsbruck, Austria, and ${ }^{3}$ Department of Experimental Psychology and Medical Research Council and \\ Wellcome Trust Behavioural and Clinical Neuroscience Institute, University of Cambridge, Cambridge CB2 3EB, United Kingdom
}

Fear extinction is a form of new learning that results in the inhibition of conditioned fear. Trait deficits in fear extinction are a risk factor for anxiety disorders. There are few examples of naturally occurring animal models of impaired extinction. The present study compared fear extinction in a panel of inbred mouse strains. This strain survey revealed an impairment in fear extinction in 129/SvImJ (129S1). The phenotypic specificity of this deficit was evaluated by comparing $129 \mathrm{~S} 1$ and C57BL/6J for one-trial and multitrial fear conditioning, nociception, and extinction of conditioned taste aversion and an appetitive instrumental response. 129S1 were tested for sensitivity to the extinction-facilitating effects of extended training, as well as D-cycloserine and yohimbine treatment. To elucidate the neural basis of impaired 129S1 fear extinction, c-Fos and Zif268 expression was mapped after extinction recall. Results showed that impaired fear extinction in 129S1 was unrelated to altered fear conditioning or nociception, and was dissociable from intact appetitive extinction. Yohimbine treatment facilitated extinction in 129S1, but neither extended extinction training nor D-cycloserine treatment improved 129S1 extinction. After extinction recall, 129S1 showed reduced c-Fos and Zif268 expression in the infralimbic cortex and basolateral amygdala, and elevated c-Fos or Zif268 expression in central nucleus of the amygdala and medial paracapsular intercalated cell mass, relative to C57BL/6J. Collectively, these data demonstrate a deficit in fear extinction in 129S1 associated with a failure to properly engage corticolimbic extinction circuitry. This common inbred strain provides a novel model for studying impaired fear extinction in anxiety disorders.

Key words: fear; extinction; anxiety; gene; prefrontal cortex; amygdala; intercalated cell masses

\section{Introduction}

Fear extinction is a form of learning in which the expression of a conditioned fear response is reduced after repeated experience of a conditioned stimulus in the absence of an unconditioned aversive stimulus (Pavlov, 1927). There is growing evidence that fear conditioning and fear extinction are independent forms of learning that are mediated by partially dissociable neural mechanisms (Kamprath and Wotjak, 2004; Quirk and Mueller, 2007; Myers and Davis, 2007). Fear conditioning and short-term extinction appear to be principally amygdala-mediated, whereas the ability to form and express extinction memory over the long term recruits the rodent ventromedial prefrontal cortex and homolo-

\footnotetext{
Received 0ct. 30, 2007; revised June 5, 2008; accepted June 25, 2008.

This work was supported by National Institute of Alcohol Abuse and Alcoholism Intramural Research Program Grant Z01-AA000411 and Fonds zur Förderung der Wissenschaftlichen Forschung Grant NFN-S102 (N.S.). We are grateful to Benjamin Palachick and Michael Feyder for technical assistance, Laura Jacobson for helpful advice on conditioned taste aversion methodology, and Francesco Ferraguti, Denis Pare, and Gregory Quirk for discussion of the ITC masses.

*K.H. and N.W. contributed equally to this work.

Correspondence should be addressed to Dr. Andrew Holmes, Section on Behavioral Science and Genetics, Laboratory for Integrative Neuroscience, National Institute on Alcohol Abuse and Alcoholism, 5625 Fishers Lane, Room 2N09, Rockville, MD 20852-9411. E-mail: holmesan@mail.nih.gov.

DOI:10.1523/JNEUROSCI.4904-07.2008

Copyright $\odot 2008$ Society for Neuroscience $\quad 0270-6474 / 08 / 288074-12 \$ 15.00 / 0$
}

gous regions in the human brain (Maren and Quirk, 2004; Phelps et al., 2004).

At the molecular level, extinction acquisition deficits are caused, for example, by upregulation of cyclin-dependent kinase 5 (Sananbenesi et al., 2007), L-type voltage-gated calcium channel blockers (Cain et al., 2002), overexpression of type I adenylyl cyclase (Wang et al., 2004), metabotropic glutamate mGluR1 antagonism (Kim et al., 2007a), or cannabinoid receptor CB-1 inactivation (Marsicano et al., 2002; Chhatwal et al., 2005), whereas extinction facilitation is produced, for instance, by NMDA receptor (NMDAR) partial agonism (Davis et al., 2006), metabotropic glutamate mGluR7 activation (Fendt et al., 2008), histone deacetylase inhibition (Lattal et al., 2007), dopamine $\mathrm{D}_{2}$ receptor antagonism (Ponnusamy et al., 2005), cyclin-dependent kinase 5 inactivation (Hawasli et al., 2007), protein kinase A inhibition (Isiegas et al., 2006), AMPA receptor potentiating (Zushida et al., 2007), or noradrenaline (Ouyang and Thomas, 2005; Berlau and McGaugh, 2006) or $\alpha 2$-adrenoreceptor antagonism (Cain et al., 2004). In addition, the mitogen-activated protein kinase (MAPK) signaling pathway is activated in the amygdala of rats and mice during fear extinction ( $\mathrm{Lu}$ et al., 2001; Lin et al., 2003a,b; Chen et al., 2005; Herry et al., 2006), whereas preextinction intraamygdala administration of MAPK or inhibitors im- 
pairs fear extinction (Lu et al., 2001; Lin et al., 2003b; Herry et al., 2006).

Fear extinction is readily quantifiable in laboratory rodents, providing important behavioral models for translational studies of anxiety disorders (Cryan and Holmes, 2005; Quirk and Beer, 2006). Such models can be applied in a variety of ways; for example, phenotypic surveys of mouse inbred strains provide a valuable approach to identifying genetically associated variation in behavior and neural circuitry (Wahlsten et al., 2006). To date, however, the majority of inbred mouse studies of fear extinction have used the commonly used C57BL/6 inbred strain or related substrains (Radulovic et al., 1998; Stiedl et al., 1999; Siegmund et al., 2005), and there has been limited study of potential strain differences in fear extinction (Falls et al., 1997; Stiedl et al., 1999; McCaughran et al., 2000; Waddell et al., 2004). Therefore, in the present study, we conducted a survey of fear extinction across a panel of inbred mouse strains. This identified the 129S1 strain as exhibiting a significant deficit in fear extinction. We went on to determine the behavioral specificity of this extinction deficit, and the sensitivity of this strain to putative extinction-facilitating behavioral and pharmacological interventions. Next, we sought to elucidate the neural basis of the fear extinction impairment in the 129S1 strain by quantifying extinction-induced activation of the immediate-early genes (IEGs) in a cortico-amygdala circuit mediating fear extinction across species (Paré et al., 2004; Phelps et al., 2004; Milad et al., 2006; Wellman et al., 2007). Both c-Fos and Zif268 were measured, given previous evidence that these IEGs show differential patterns of extinction-induced activation (Herry and Mons, 2004). The results reveal a model of impaired fear extinction in a common inbred strain associated with a failure to recruit the key neural circuitry necessary for extinction.

\section{Materials and Methods}

Subjects. Subjects were male 129S1/SvImJ, A/J, BALB/cByJ, C57BL/6J, $\mathrm{DBA} / 2 \mathrm{~J}$, and $\mathrm{FVB} / \mathrm{NJ}$ strains. These strains were chosen on the basis of their frequent use in behavioral neuroscience, including as genetic backgrounds for mutants and inclusion as "group A" priority strains in the Mouse Phenome Project, an international effort to provide the biomedical research community with phenotypic data on the most commonly used mouse strains (www.jax.org/phenome). For experiments conducted at the National Institutes of Health, mice were obtained at $\sim 8$ weeks of age from The Jackson Laboratory and housed (two to four per cage) side-by-side in a temperature $\left(22 \pm 1{ }^{\circ} \mathrm{C}\right)$ - and humidity $(45 \pm$ $15 \%$ )-controlled vivarium under a $12 \mathrm{~h}$ light/dark cycle (lights on, 6:00 A.M.). The IEG activation experiments were conducted in Innsbruck. These mice were obtained from Charles River and housed (four to five per cage) side-by-side in a temperature $\left(22 \pm 2^{\circ} \mathrm{C}\right)$ - and humidity $(50-$ $60 \%$ )-controlled vivarium under a $12 \mathrm{~h}$ light/dark cycle (lights on, 7:00 A.M.). The number of mice used in each experiment is given in the figure legends. All experimental procedures were approved by the National Institute on Alcohol Abuse and Alcoholism Animal Care and Use and Austrian Ethical Committees on Animal Care and Use (Bundesministerium für Wissenschaft und Forschung) and followed the National Institutes of Health guidelines outlined in Using Animals in Intramural Research and the local animal care and use committees.

Strain survey of fear extinction. Fear extinction was assessed based on methods described previously (Izquierdo et al., 2006a). Mice were moved to a holding room adjacent to the test room and acclimated for $1 \mathrm{~h}$ before testing. Fear conditioning was conducted in a $27 \times 27 \times 11 \mathrm{~cm}$ chamber with transparent walls and a metal rod floor, cleaned with a $79.5 \%$ water/ $19.5 \%$ ethanol $/ 1 \%$ vanilla extract solution to provide a distinctive olfactory cue. After $180 \mathrm{~s}$, mice received three pairings $(60-120 \mathrm{~s}$ variable interpairing interval) between a $30 \mathrm{~s}, 80 \mathrm{~dB}, 3 \mathrm{kHz}$ tone [conditioned stimulus (CS)] and a $2 \mathrm{~s}, 0.6 \mathrm{~mA}$ scrambled footshock [unconditioned stimulus (US)], in which the shock was presented during the last $2 \mathrm{~s}$ of the CS. There was a $120 \mathrm{~s}$ no-stimulus consolidation period after the final
US-CS pairing before mice were returned to the home cage. Stimulus presentation was controlled by the MED Associates VideoFreeze system.

Twenty-four hours later, initial fear recall and within-session fear extinction were tested. Mice were placed in a novel context (black/whitecheckered walls, solid-Plexiglas, opaque floor, cleaned with a $70 \%$ ethanol $/ 30 \%$ water solution), housed in a different room from conditioning. After $180 \mathrm{~s}$, there were $50 \times 30 \mathrm{~s}$ CS presentations ( $5 \mathrm{~s}$ no-stimulus interval). Twenty-four hours later, extinction recall was tested using the same procedure as the previous day.

Freezing was measured as an index of fear (Blanchard and Blanchard, 1969), and manually scored every $5 \mathrm{~s}$ as no visible movement except that required for respiration and converted to a percentage [(number of freezing observations/total number of observations) $\times 100$ ]. Freezing during conditioning was measured during the baseline period and each of the three CS presentations. Freezing during extinction and extinction recall was binned into $3 \times \mathrm{CS}$ trial blocks.

Behavioral specificity of extinction deficit in the 12951 strain. On the basis of the strain comparison data revealing a marked deficit in fear extinction in the 129S1 strain, we next assessed the behavioral specificity of the deficit in this strain.

Fear conditioning. Failure of $129 \mathrm{~S} 1$ to show extinction could result from either an extinction deficit per se or an inability of an intact extinction memory to overcome an excessive fear memory. We therefore examined whether impaired fear extinction in 129S1 mice was dissociable from an increase in fear. In one experiment, 129S1 (and for comparison, $\mathrm{C} 57 \mathrm{BL} / 6 \mathrm{~J}$ ) mice were conditioned using the same three tone-shock protocol described above and, $24 \mathrm{~h}$ later, tested for fear recall via average freezing over three CS presentations (Yang et al., 2008). Because three tone-shock pairings during conditioning could conceivably produce ceiling levels of fear during recall, an additional experiment was conducted in the same manner with the exception that there was only one tone-shock pairing during conditioning.

Nociception. To exclude the possibility that increased pain perception could confound fear extinction, 129S1 (and for comparison, C57BL/6J) mice were tested on the hot plate and Von Frey tests. The hot plate test apparatus was a flat plate (Columbus Instruments) heated to $55^{\circ} \mathrm{C}$ on which the mouse was placed (Boyce-Rustay and Holmes, 2006). The latency to show a hindpaw shake or lick was manually timed, with a maximum response latency of $30 \mathrm{~s}$. For the Von Frey test, the threshold value for hindpaw withdrawal in response to punctate mechanical stimulation was measured with graded Von Frey filaments (Stoelting) (Hasnie et al., 2007). Each mouse was given 2 min of acclimation to the wire mesh cage and then tested on the right hindpaw. Threshold response was defined by the filament that caused active paw withdrawal at least three times for every five applications. There were two trials separated by a 2 min interval (average $=$ withdrawal threshold).

Extinction of appetitive instrumental response. We next evaluated extinction to a nonaversive, appetitively motivated form of learning. 129S1 (and for comparison, C57BL/6J) were tested for extinction of an instrumental response using a touchscreen-based operant system described previously [for details of apparatus, see Izquierdo et al. (2006b) and Brigman et al. (2008)]. Food-restricted mice were acclimated to the 14 mg pellet food reward and to eating the rewards from the pellet magazine. Mice then underwent pavlovian autoshaping during which variously shaped stimuli were presented in the touchscreen windows (one per window) for $10 \mathrm{~s}$ [intertrial interval (ITI), $15 \mathrm{~s}$ ]. The disappearance of the stimuli coincided with provision of a single pellet food reward, and mice were required to eat the pellet for the next trial to commence. The criterion was eating 30 pellets in a $30 \mathrm{~min}$ session. There were then two stages of operant shaping: (1) respond to a (variously shaped) stimulus that appeared in one of the two windows (spatially pseudorandomized) and remained on the screen until a response was made, (2) same as (1), plus a new trial was initiated by a head entry into the pellet magazine. Criterion for each shaping stage was $90 \%$ responding in a 30 trial session $(15 \mathrm{~s}$ ITI).

For the task proper, mice were required to respond to stimuli $(1 \times 2.8$ $\mathrm{cm}^{2}$ white square per window) to obtain reward. Stimuli remained on the screen until a response was made, with 30 trials ( $5 \mathrm{~s}$ ITI) per session. Criterion was performing 30 trials within $12.5 \mathrm{~min}$ on each of five con- 
secutive sessions. Next, extinction of the response was tested in sessions during which responses to the stimulus were no longer rewarded. Criterion was a two session average of $75 \%$ or more response omissions. The dependent measure was the number of trials to reach the acquisition and extinction criteria.

Extinction of conditioned taste aversion. To assess whether impaired fear extinction occurred in another test of extinction to an aversive learning event, 129S1 (and for comparison, C57BL/6J) were tested for extinction of a conditioned taste aversion (CTA) as described previously (Jacobson et al., 2006). Singly housed mice were first water-deprived and habituated to drinking from two water-filled sipper tubes offered in the cage for 30 min twice per day (morning, evening) for $6 \mathrm{~d}$. On day 7 , mice were offered only one tube, containing $0.5 \%$ saccharin, during the morning presentation. Thirty minutes after the 30 min presentation, mice were given an intraperitoneal injection of 0.15 $\mathrm{M} \mathrm{LiCl}$ in volume of $20 \mathrm{ml} / \mathrm{kg}(=0.30 \mathrm{M})$ and observed for signs of malaise. Malaise was defined as protracted periods of nonsleeping immobility, piloerection, contraction of the flanks, prostrate, flat belly, and elongated body posture (mice displaying malaise were given a score of 1). Mice were offered water during the 5:00 P.M. presentation to prevent excessive dehydration.

Extinction was assessed over 13 daily sessions. The procedure was the same as for habituation days, except that mice were offered two tubes, one containing $0.5 \%$ saccharin and one containing water, for 40 min during each twice daily presentation, with the left/right side of the water- versus saccharin-containing tubes counterbalanced across days and experimental groups. A daily aversion index was calculated as fluid consumed from water-contained tube/total fluid consumed from both tubes; with an index score closer to 1.0 indicating maximum aversion.

To assess unconditioned saccharin preference, an additional experiment was conducted in naive mice. Mice were tested as above with the exception that $\mathrm{LiCl}$ was replaced with saline, and saccharin preference was measured on days $8-10$ only.

Behavioral and pharmacological influences on fear extinction in 129 S1. We next conducted a series of experiments to test whether the extinction deficit in 129S1 mice was rescued by behavioral or pharmacological manipulations.

Extended massed-trial extinction. To examine whether 12951 mice would demonstrate extinction over an extended massed-trial extinction protocol, mice were tested on a 100 trial extinction protocol followed by a 50 trial extinction recall protocol.

Effects of D-cycloserine treatment. Systemic treatment with the NMDAR partial agonist D-cycloserine facilitates fear extinction in rodents and has proven to be effective as an adjunct to exposure therapy in human anxiety disorders (Davis et al., 2006). We therefore assessed the ability of D-cycloserine to facilitate impaired extinction in 129S1 mice. 129S1 mice underwent three tone-shock conditioning as above and, $24 \mathrm{~h}$ later, treated with saline vehicle or 5, 15, or $30 \mathrm{mg} / \mathrm{kg}$ (injected intraperitoneally in a volume of $10 \mathrm{ml} / \mathrm{kg}$ body) D-cycloserine (Sigma-Aldrich) $30 \mathrm{~min}$ before 50 trial extinction testing. Mice were tested, drug-free, $24 \mathrm{~h}$ later for fear via average freezing over $3 \times$ tone presentations. Because the effects of D-cycloserine have not been demonstrated in our fear extinc-
DBA/2J

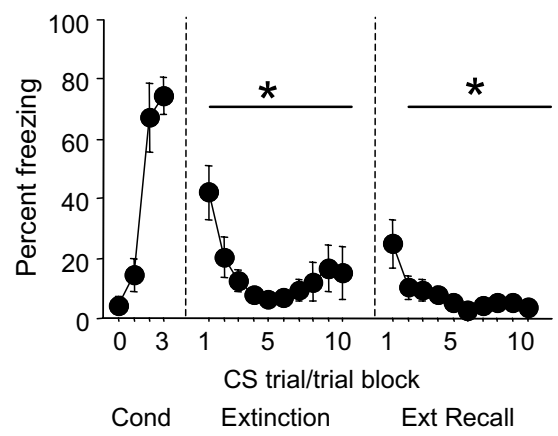

BALB/cByJ

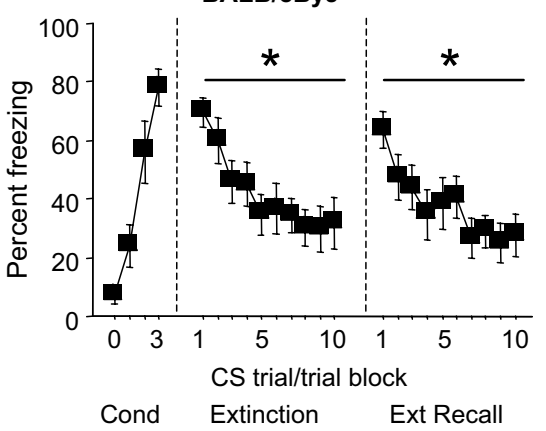

$129 S 1$ (S1)

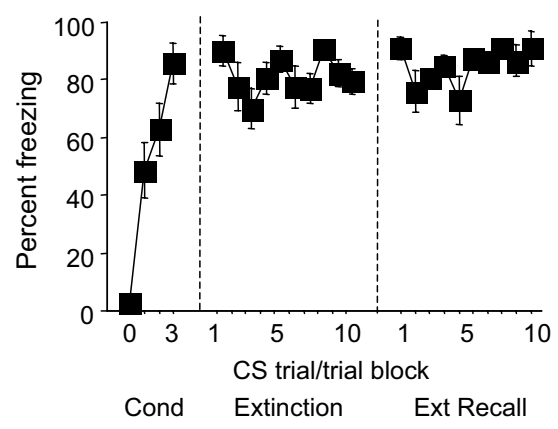

FVB/NJ

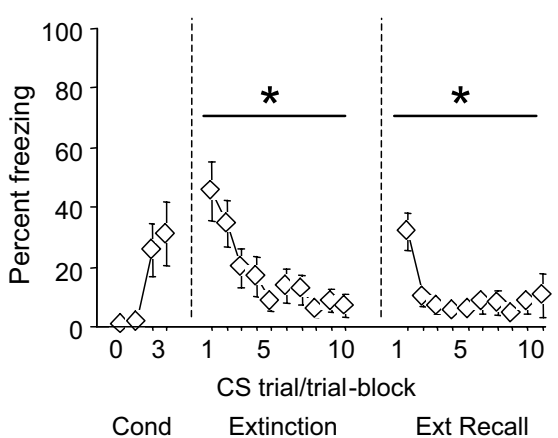

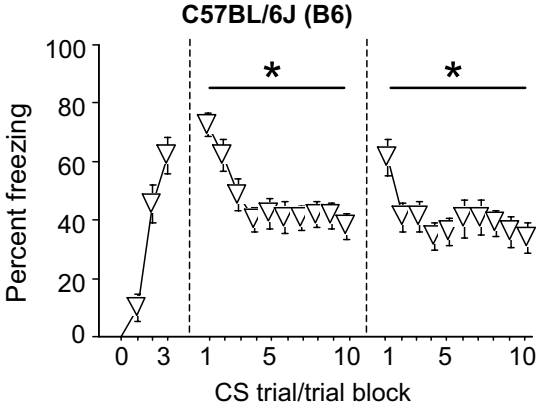

Cond Extinction

Ext Recall

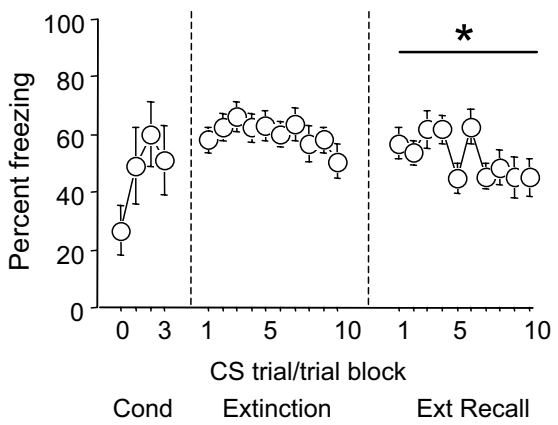

Figure 1. Survey of fear extinction across inbred strains. All strains except 12951 showed a significant reduction in conditioned fear over at least one extinction session. Cond, Conditioning; Ext recall, extinction recall. $n=7-14 /$ strain. ${ }^{*} p<0.05$, significant change over trials. Data in Figures $1-7$ are means \pm SEM.

tion paradigm in C57BL/6J, we also tested the drug in this strain. Doses were chosen based on extinction facilitating doses of D-cycloserine in rats and humans (Walker et al., 2002; Ressler et al., 2004; Richardson et al., 2004).

Effects of yohimbine treatment. Systemic treatment with the $\alpha 2$ adrenoreceptor antagonist yohimbine has been shown to improve fear extinction in mice (Cain et al., 2004). We therefore also tested the effects of this drug in 129S1 mice. The procedure was the same as for D-cycloserine. Doses of 2.5 and $5 \mathrm{mg} / \mathrm{kg}$ yohimbine (Sigma-Aldrich) were chosen based on extinction facilitating doses of the drug in C57BL/6J mice (Cain et al., 2004).

Extinction-related cortico-amygdala IEG activation. We next sought to identify neural correlates of the extinction deficit in 129S1 using IEG expression as a marker for neuronal activity (Singewald, 2007). The focus of this analysis was a prefrontal cortex-amygdala circuit that has been consistently shown to be recruited during extinction in rodents and humans (Paré et al., 2004; Phelps et al., 2004; Quirk et al., 2006). For these experiments, $129 \mathrm{~S} 1$ were compared with C57BL/6J. Mice underwent fear conditioning in a $26 \times 30 \times 32 \mathrm{~cm}$ chamber with transparent walls and a metal rod floor. After $120 \mathrm{~s}$, mice received five pairings (120 s interpair- 
ing interval) between a $120 \mathrm{~s}, 80 \mathrm{~dB}$ white noise and a $2 \mathrm{~s}, 0.7 \mathrm{~mA}$ scrambled footshock, in which the shock was presented during the last $2 \mathrm{~s}$ of the tone. There was a $120 \mathrm{~s}$ no-stimulus consolidation period after the final tone-shock pairing before mice were returned to the home cage. A nonconditioned control group ("CS minus baseline") underwent the same procedure except there was no footshock exposure. Stimulus presentation was controlled by the Habitest operant system (Coulbourn Instruments). Twenty-four hours later, mice were placed in a novel context $(26 \times 20 \times 13 \mathrm{~cm}$ cage, cleaned with a $100 \%$ ethanol, illuminated to 10 lux) for a $120 \mathrm{~s}$ acclimation period and then exposed to $15 \times 120 \mathrm{~s}$ tone presentations ( $5 \mathrm{~s}$ no-stimulus interval). Twenty-four hours later, mice were returned to the novel context, exposed (after a $120 \mathrm{~s}$ acclimation period) to $15 \times 120 \mathrm{~s}$ tone presentations, and killed for immediate-early gene analysis $2 \mathrm{~h}$ after the start of the session [time interval according to postextinction c-Fos and Zif268 data obtained by Herry and Mons (2004)].

For IEG analysis, mice were deeply anesthetized with an overdose of sodium pentobarbital $(200 \mathrm{mg} / \mathrm{kg})$ and transcardially perfused with 20 $\mathrm{ml}$ of $0.9 \%$ saline followed by $20 \mathrm{ml}$ of $4 \%$ paraformaldehyde in $0.1 \mathrm{~mol} / \mathrm{L}$ $\mathrm{PBS}, \mathrm{pH}$ 7.4. Brains were then removed and postfixed at $4^{\circ} \mathrm{C}$ overnight in $4 \%$ paraformaldehyde in PBS. Coronal sections $(50 \mu \mathrm{m})$ were cut with a vibratome (Ted Pella) and collected in immunobuffer. The sections were processed for (1) c-Fos immunoreactivity as described previously (Singewald et al., 2003), via incubation with a polyclonal primary antibody (1:20,000; sc-52; Santa Cruz Biotechnology), and (2) Zif268-like immunoreactivity via incubation with a polyclonal primary antibody (1:5000; sc-189; Santa Cruz Biotechnology) and a biotinylated goat antirabbit secondary antibody (1:200; Vector Laboratories). Cells containing a nuclear brown-black reaction product were considered to be c-Fospositive or Zif268-positive cells, respectively. The anatomical localization of c-Fos-positive or Zif268-positive cells was aided by using the illustrations in a stereotaxic atlas (Paxinos and Franklin, 2001). Zif268positive neurons in intercalated (ITC) cell masses were identified with reference to published studies in the rat and mouse (Millhouse, 1986; Berretta et al., 2005; Marowsky et al., 2005; Geracitano et al., 2007). One mass of ITC cells situated along the external capsule at the junction of lateral nucleus of the amygdala (LA) and the basolateral nucleus of the amygdala (BLA) was identified as lateral paracapsular ITC neurons (Ilp). A second mass of ITC cells was observed along the intermediate capsule at the junction of LA/BLA and lateral to the central nucleus of the amygdala (CeA) and was defined as the medial paracapsular ITC mass (Imp) (see Fig. 7A). Aiding the identification of ITC cell masses, the size of Zif268-labeled nuclei in the masses was considerably smaller than those in the adjacent BLA and CeA (ITCs, $21.9 \pm 3.3 \mu \mathrm{m}^{2}$; BLA, $45.2 \pm 3.0$; CeA, $40.5 \pm 3.8$; one-factor ANOVA, $F_{(2,60)}=102.98, p<0.01$; Bonferroni's post hoc comparisons, $p<0.01$ ). Unless otherwise stated, all c-Fospositive or Zif268-positive cells that were distinguishable from background staining were bilaterally counted in each region of interest within a defined area $\left(0.01 \mathrm{~mm}^{2}\right)$ averaging counts from two to four sections per mouse depending on the brain area under investigation.

Fear-related cortico-amygdala IEG activation. To test for possible strain differences in immediate-early gene activation after fear recall per se, an additional control experiment was conducted. 129S1 and C57BL/6J mice were conditioned as above for extinction-related immediate-early gene analysis and, $24 \mathrm{~h}$ later, exposed to $1 \times 30 \mathrm{~s}$ tone presentation before being killed and processed for immediate-early gene analysis $2 \mathrm{~h}$ later, as above.

Statistics. The effects of strain $\times$ tone-trial/block, session, or day on freezing, instrumental responses, or taste aversion index were analyzed using two-factor ANOVA, with repeated measures for tone-trial/block, session, or day, followed by Bonferroni's post hoc analysis. In the presence of a significant interaction in this initial strain profile, within-session strain profiles were either analyzed via separate repeated-measures ANOVA. Effects of strain and condition on IEG expression after fear recall were analyzed using unpaired $t$ tests. Effects of strain by condition on IEG expression after fear recall were analyzed using two-factor ANOVA followed by Bonferroni's post hoc analysis. Correlations between freezing during extinction recall and number of c-Fos and Zif268 cells were performed using the Spearman's coefficient test. The threshold

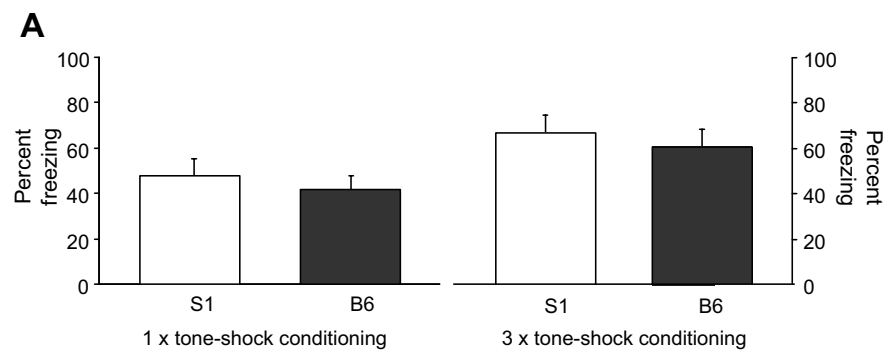

B

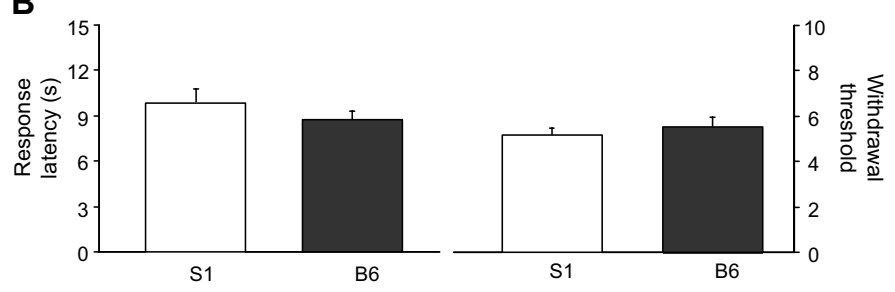

Figure 2. Fear conditioning and nociception in 12951 mice. $A$, Fear recall was no different between 12951 (S1) and C57BL/6J (B6) after either $1 \times$ tone-shock conditioning $(n=15$ / strain) or $3 \times$ tone-shock conditioning $(n=15 /$ strain). $\boldsymbol{B}$, Nociceptive responses were no different between $\mathrm{S} 1$ and B6 in either the hot plate or von Frey tests ( $n=11 /$ strain).

for statistical significance was set at $p<0.05$ (statistical results below this threshold are not described).

\section{Results}

\section{Strain survey of fear extinction}

There was a significant strain $\times$ tone-trial/block interaction for freezing during conditioning $\left(F_{(15,186)}=3.43 ; p<0.01\right)$, extinction $\left(F_{(45,558)}=2.67 ; p<0.01\right)$, and extinction recall $\left(F_{(45,558)}=\right.$ $1.86 ; p<0.01)$ sessions. For clarity, the profiles of each of the six strains are presented separately in Figure 1. During conditioning, all strains showed a significant increase in freezing across trials (all $p<0.01$ ) with the exception of $\mathrm{A} / \mathrm{J}$, which had high baseline freezing. During extinction, DBA/2J, FVB/NJ, BALB/cByJ, and C57BL/6J showed a significant decrease in freezing across trialblocks (all $p<0.01$ ). Neither A/J nor $129 S 1$ showed a significant decrease in freezing during the extinction session. All strains (all $p<0.01$ ) except 129S1 displayed a significant decrease in freezing during the extinction recall session.

\section{Behavioral specificity of extinction deficit in the 129S1 strain Fear conditioning}

There were no differences between 129S1 and C57BL/6J in fear recall after either $3 \times$ tone-shock (Fig. $2 A$, right) or $1 \times$ toneshock (Fig. $2 \mathrm{~A}$, left) conditioning protocols.

\section{Nociception}

Neither hot plate response latencies (Fig. 2B, left) nor Von Frey responses (Fig. 2 B, right) differed between $129 \mathrm{~S} 1$ and C57BL/6J.

\section{Extinction of appetitive instrumental behavior}

There was no significant effect of strain for trials to extinguish the instrumental behavior (129S1, $130 \pm 18$ trials; C57BL/6J, $120 \pm$ 7 trials) (sessions 1-5 are shown in Fig. $3 A$ ). There was a significant effect of strain for trials to acquire an appetitively driven instrumental response behavior $\left(F_{(1,18)}=4.70 ; p<0.05\right)$ because of faster learning in $129 \mathrm{~S} 1$ ( $8.7 \pm 1.4$ trials to criterion) than C57BL/6J (13.4 \pm 1.6 trials to criterion).

\section{Extinction of conditioned taste aversion}

There was a significant strain by day interaction for aversion index during CTA extinction $\left(F_{(12,192)}=2.92 ; p<0.01\right)$. The 

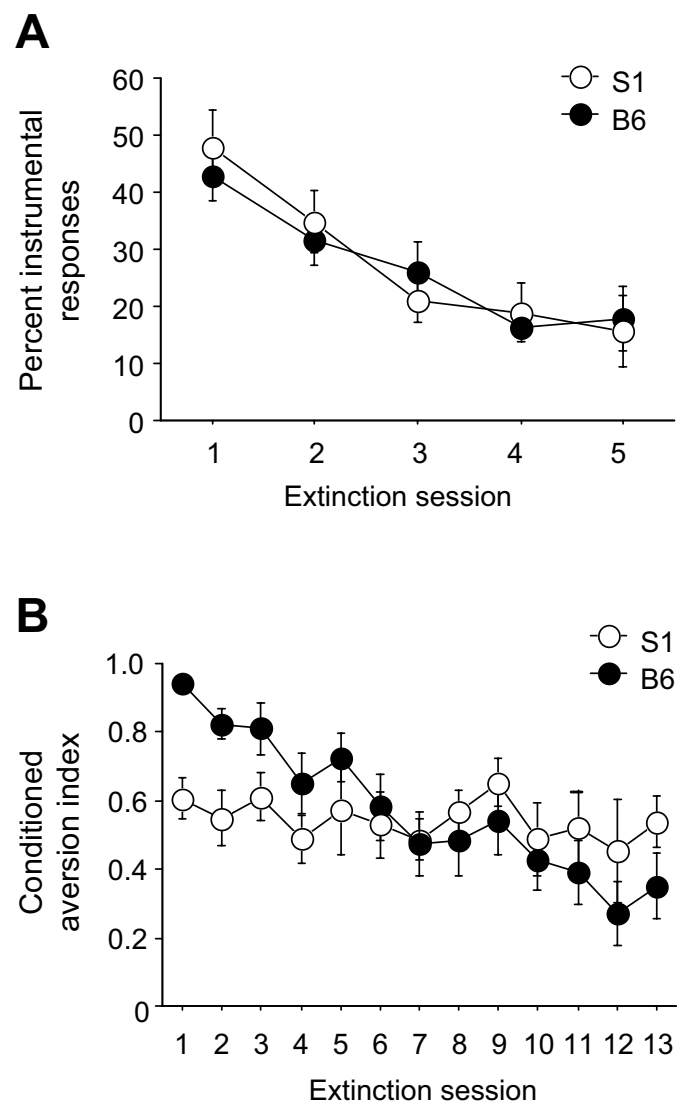

Figure 3. Extinction of an appetitive instrumental behavior and extinction of conditioned taste aversion in 12951 mice. $A, 12951$ (S1) and $C 57 \mathrm{BL} / 6 \mathrm{~J}$ (B6) showed similar rates extinction of an appetitively motivated instrumental response ( $n=9-11 / s$ train). $\boldsymbol{B}, 12951$ showed lesser initial expression of conditioned taste aversion and no reduction in the aversion over extinction sessions, compared with B6 ( $n=9 /$ strain).

aversion index in C57BL/6J was significantly higher than in 129S1 during the first two sessions $(p<0.01)$, and there was a significant decrease in the aversion index across sessions in C57BL/6J $\left(F_{(12,96)}=17.26 ; p<0.01\right)$ but not 129S1 (Fig. 3B). Malaise scores were no different between strains $(129 \mathrm{~S} 1=0.58 \pm 0.11$; C57BL/ $6 \mathrm{~J}=0.47 \pm 0.12)$. Unconditioned C57BL/6J showed a clear preference for saccharin over water $(80 \pm 4.4 \%$ preference), whereas unconditioned $129 S 1$ showed no preference $(49 \pm 5.9 \%$ preference) ( $n=7 /$ strain $)$.

\section{Behavioral and pharmacological influences on fear extinction in $129 \mathrm{~S} 1$}

Extended massed-trial extinction

129S1 showed no decrease in freezing over two sessions in an extended massed-trial protocol (Fig. 4A).

\section{Effects of D-cycloserine}

There was no significant effect of D-cycloserine treatment on freezing during extinction recall in 129S1 mice (Fig. 4B). D-Cycloserine treatment significantly reduced freezing during extinction recall in C57BL/6J mice $\left(F_{(3,49)}=2.80, p=0.05\right.$; vehicle, $72.0 \pm 6.2 \% ; 5 \mathrm{mg} / \mathrm{kg}, 50.7 \pm 6.4 \% ; 15 \mathrm{mg} / \mathrm{kg}, 52.6 \pm 4.8 \%$; $30 \mathrm{mg} / \mathrm{kg}, 53.1 \pm 6.0 \% ; p<0.05$, all doses vs vehicle; $n=$ $12-14 /$ dose).

\section{Effects of yohimbine}

There was a significant effect of yohimbine treatment on freezing during extinction recall $\left(F_{(2,26)}=5.16 ; p<0.05\right)$. Mice previ-
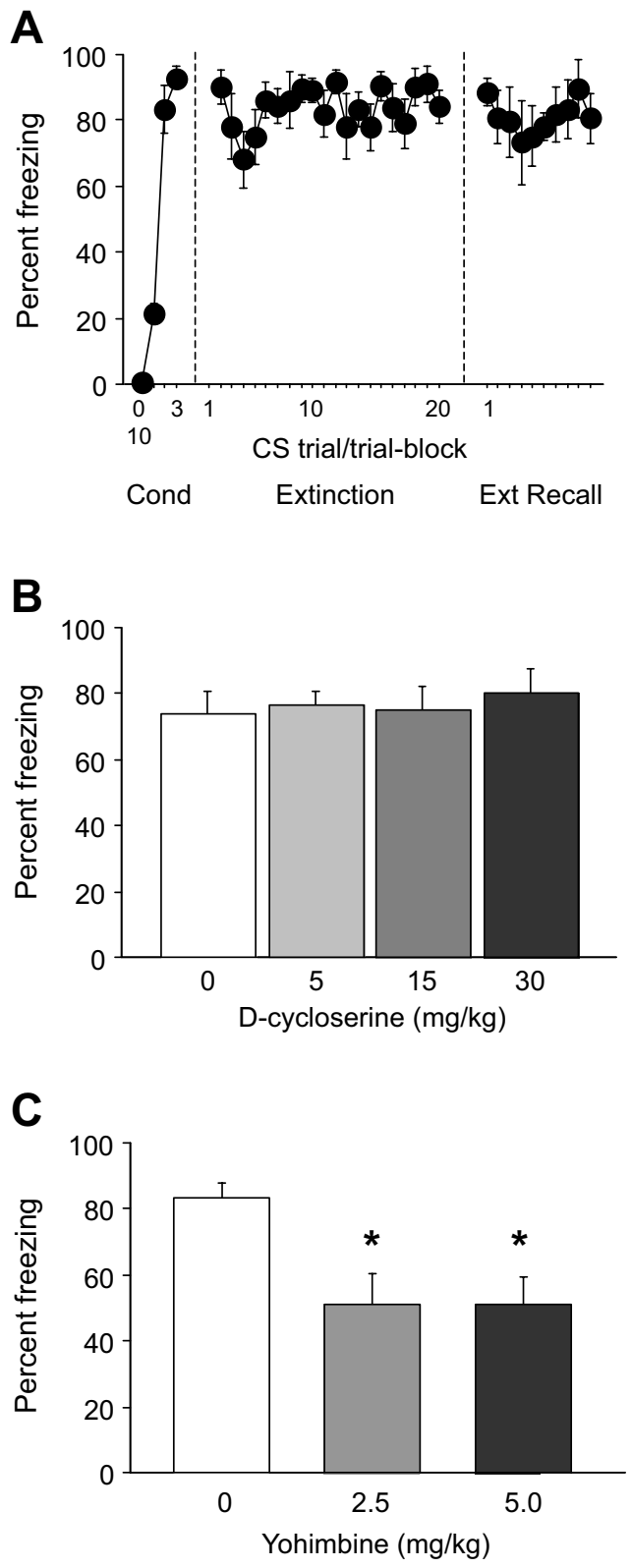

Figure 4. Effects of behavioral and pharmacological manipulations on fear extinction in 12951 mice. $\boldsymbol{A}$, Extended massed-trial extinction did not reduce conditioned fear $(n=7)$. $\boldsymbol{B}$, $\mathrm{D}$-Cycloserine treatment during extinction did not reduce conditioned fear during extinction recall ( $n=9 /$ dose). C, Yohimbine treatment during extinction significantly reduced conditioned fear during extinction recall relative to vehicle treatment $\left(n=9-10 /\right.$ dose). ${ }^{*} p<0.05$ versus vehicle.

ously treated with either 2.5 or $5.0 \mathrm{mg} / \mathrm{kg}$ showed significantly less freezing than vehicle-treated controls (Fig. $4 C$ ).

\section{Extinction-related cortico-amygdala IEG activation}

$129 \mathrm{~S} 1$ showed significantly more freezing than C57BL/6J over the extinction recall session (129S1, $65.3 \pm 1.6 \%$; C57BL/6J, $4.5 \pm$ $\left.0.9 \% ; t_{(13)}=12.58 ; p<0.01\right)$ and the first tone presentation per se (129S1, 74.0 \pm 5.4\%; C57BL/6J, $23.8 \pm 5.1 \% ; t_{(13)}=6.72 ; p<$ $0.01)$. There was a significant strain by condition interaction for the number of c-Fos-positive cells in the infralimbic cortex (IL) $\left(1.78 \mathrm{~mm}\right.$ from bregma, $F_{(1,19)}=34.55, p<0.01 ; 1.54 \mathrm{~mm}$ from bregma, $\left.F_{(1,19)}=9.47, p<0.01\right)$, the basolateral $\left(F_{(1,19)}=38.43\right.$; $p<0.01)$ and central nucleus $\left(F_{(1,19)}=15.72 ; p<0.01\right)$ of the amygdala. Although all three regions show higher c-Fos expres- 

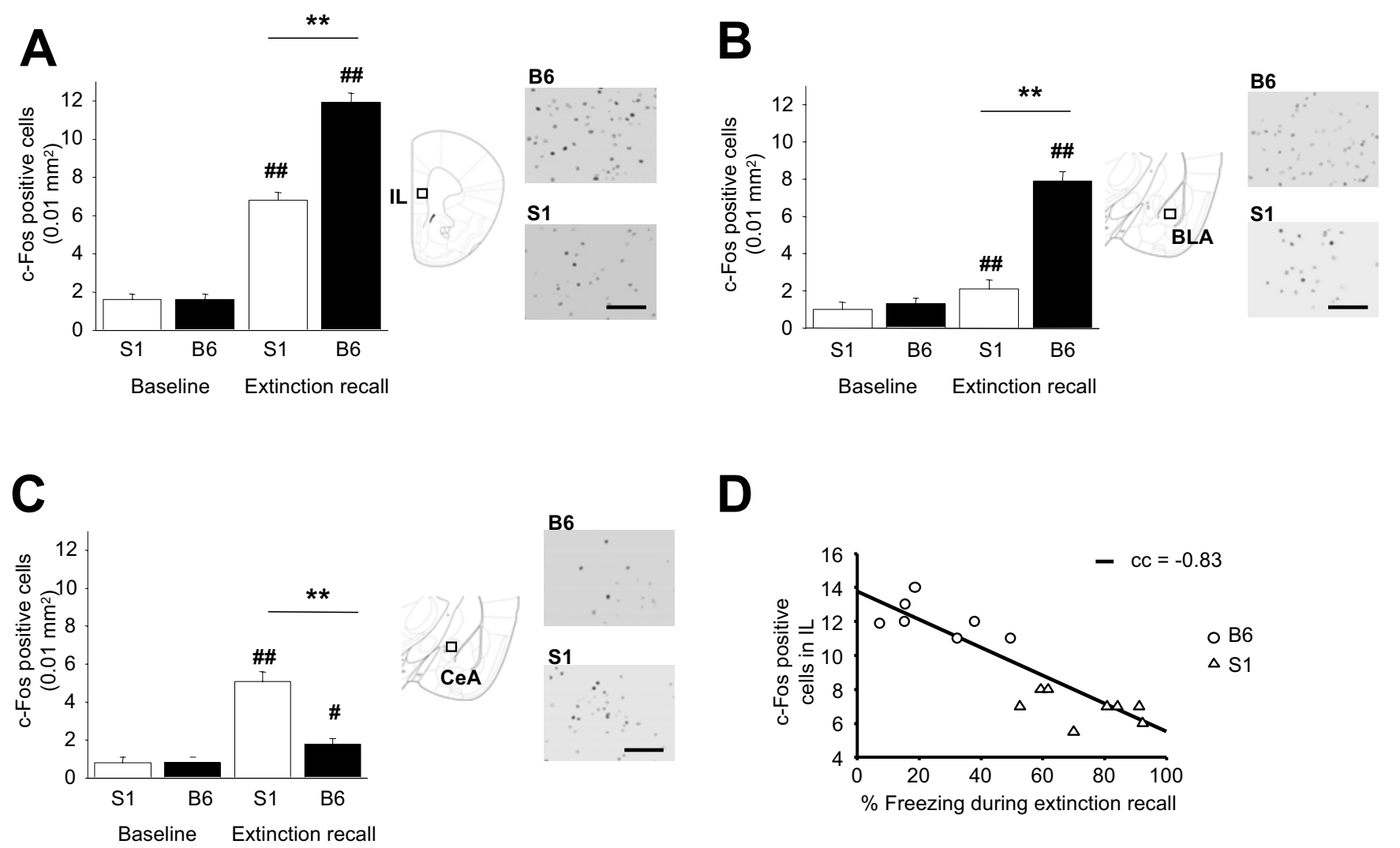

Figure 5. c-Fos expression after extinction recall. $A$, 12951 (S1) mice showed a lesser increase (relative to CS minus baseline) in c-Fos-positive cells in the IL than C57BL/6J (B6) after extinction recall. B, S1 mice showed a lesser extinction-related increase in c-Fos-positive cells in the BLA than B6 after extinction recall. C, S1 mice showed a greater increase in c-Fos-positive cells in CeA than B6 after extinction recall. $\boldsymbol{D}$, The number of c-Fos-positive cells in IL (but not BLA or CeA) (see Results) was highly negatively correlated with freezing during extinction recall. $n=7-8 /$ strain for extinction recall; $n=4$ /strain for baseline. cc, Correlation coefficient. Scale bars, $100 \mu \mathrm{m} .{ }^{* *} p<0.0112951$ versus $\mathrm{B} 6$; ${ }^{* \#} p<0.01,{ }^{\#} p<0.05$ versus baseline.

sion after extinction recall relative to CS minus baseline control levels in both strains, after extinction recall 129S1 mice exhibited fewer c-Fos-positive cells in the infralimbic cortex (Fig. $5 A$ ) and basolateral amygdala (Fig. $5 B$ ), and more positive cells in the central amygdala (Fig. 5C) than C57BL/6J. The cingulate cortex (1.78 mm from bregma, $F_{(1,19)}=68.24, p<0.01 ; 1.54 \mathrm{~mm}$ from bregma, $F_{(1,19)}=177.56, p<0.01 ; 1.10 \mathrm{~mm}$ from bregma, $F_{(1,19)}$ $=143.48, p<0.01)$, prelimbic cortex $(1.78 \mathrm{~mm}$ from bregma, $F_{(1,19)}=220.43, p<0.01 ; 1.54 \mathrm{~mm}$ from bregma, $F_{(1,19)}=$ $149.06, p<0.01)$, lateral amygdala $\left(F_{(1,19)}=35.77 ; p<0.01\right)$, medial posterodorsal $\left(F_{(1,19)}=91.49 ; p<0.01\right)$, medial posteroventral $\left(F_{(1,19)}=58.73 ; p<0.01\right)$, anterior cortical $\left(F_{(1,19)}=\right.$ $47.57 ; p<0.01)$, and posterolateral cortical $\left(F_{(1,19)}=58.88 ; p<\right.$ $0.01)$ regions all expressed significantly more c-Fos-positive cells after extinction recall than after CS minus baseline conditions but did not differ between strains (Table 1). No other brain regions examined were significantly affected by condition or strain ( Table 1).

There was a significant strain by condition interaction for the number of Zif268-positive cells in the infralimbic cortex (1.78 $\mathrm{mm}$ from bregma, $F_{(1,19)}=30.74, p<0.01 ; 1.54 \mathrm{~mm}$ from bregma, $\left.F_{(1,19)}=14.32, p<0.01\right)$, the lateral $\left(F_{(1,19)}=17.22 ; p<\right.$ $0.01)$ and basolateral nuclei of the amygdala $\left(F_{(1,19)}=33.97 ; p<\right.$ $0.01)$, and the Imp ITC mass $\left(F_{(1,19)}=23.80 ; p<0.01\right)$. Although these five regions show higher Zif268 expression after extinction recall relative to CS minus baseline control levels in both strains, after extinction recall 129S1 mice exhibited fewer Zif268-positive cells in the infralimbic cortex (Fig. 6A) and lateral amygdala (Fig. $6 B$ ), and more positive cells in Imp (Fig. $7 B$ ) than C57BL/6J. The secondary motor $\left(F_{(1,19)}=153.97 ; p<0.01\right)$, cingulate cortex $\left(1.78 \mathrm{~mm}\right.$ from bregma, $F_{(1,19)}=109.96, p<0.01 ; 1.10 \mathrm{~mm}$ from bregma, $\left.F_{(1,19)}=8.88, p<0.01\right)$, prelimbic cortex $(1.78 \mathrm{~mm}$ from bregma, $F_{(1,19)}=97.41, p<0.01 ; 1.54 \mathrm{~mm}$ from bregma, $\left.F_{(1,19)}=77.67, p<0.01\right)$, central nucleus $\left(F_{(1,19)}=72.11 ; p<\right.$ $0.01)$, Ilp ITC mass $\left(F_{(1,19)}=34.25 ; p<0.01\right)$, medial posterodorsal $\left(F_{(1,19)}=155.19 ; p<0.01\right)$, medial posteroventral $\left(F_{(1,19)}=62.88 ; p<0.01\right)$, and posterolateral cortical $\left(F_{(1,19)}=\right.$ 49.56; $p<0.01)$ regions all expressed significantly more Zif268positive cells after extinction recall than after CS minus baseline but did not differ between strains (Table 2). No other brain regions examined were significantly affected by condition or strain (Table 2).

Correlational analysis of the whole sample (i.e., both strains) revealed a significant negative correlation between percentage freezing during first tone presentation during extinction recall and the number of c-Fos-positive $(-0.83, p<0.01,1.74 \mathrm{~mm}$ from bregma; $-0.75, p<0.01,1.54 \mathrm{~mm}$ from bregma) (Fig. $5 D$ ) and Zif268-positive $(-0.77, p<0.01,1.74 \mathrm{~mm}$ from bregma; $-0.80, p<0.01,1.54 \mathrm{~mm}$ from bregma) (Fig. $6 D$ ) cells in the infralimbic cortex. Significant negative correlation was also observed between extinction recall freezing and c-Fos $(-0.75 ; p<$ $0.01)$ - and Zif268 ( $-0.77 ; p<0.01)$-positive cells in the basolateral amygdala, as well as Zif268-positive cells in the lateral amygdala $(-0.79 ; p<0.01)$. Finally, there was a significant positive correlation between extinction recall freezing and the number of c-Fos-positive cells in the central amygdala $(0.87 ; p<0.01)$ and the number of Zif268-positive cells in the medial paracapsular 
A

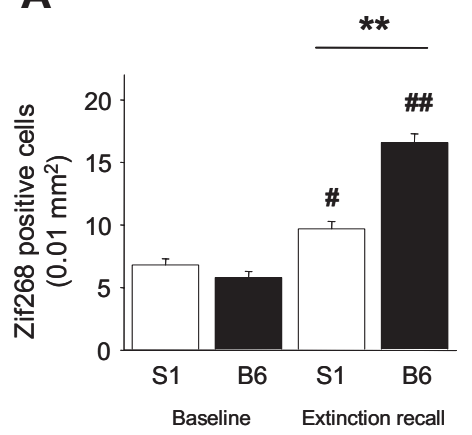

C

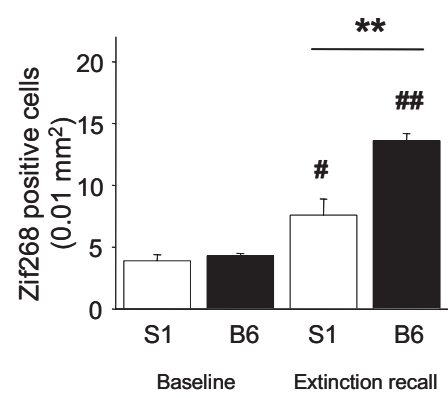

B
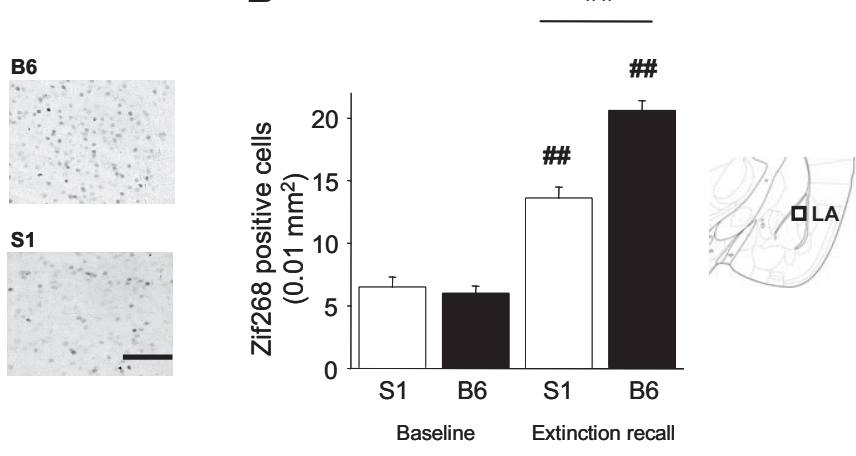

B6

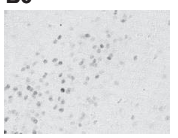

s1

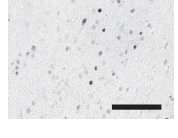

Figure 6. Zif268 expression after extinction recall. $\boldsymbol{A}, 129 \mathrm{S1}$ (S1) mice showed a lesser increase (relative to CS minus baseline) in Zif268-positive cells in the IL than C57BL/6J (B6) after extinction recall. $B$, S1 mice showed a lesser increase in Zif268-positive cells in LA than B6 after extinction recall. C, S1 mice showed a lesser increase in Zif268-positive cells in the BLA than B6 after extinction recall. $\boldsymbol{D}$, Across strains, the number of Zif268-positive cells in IL (but not BLA or (eA) (see Results) was negatively correlated with freezing during extinction recall. $n=7-8 /$ strain for extinction recall; $n=4$ /strain for baseline. cc, Correlation coefficient. Scale bar, $100 \mu \mathrm{m}$. ${ }^{* *} p<0.01129$ S1 versus B6; ${ }^{\# \#} p<0.01$, ${ }^{\#} p<0.05$ versus baseline.

ITC $(0.80 ; p<0.01)$ (Fig. $7 C$, Tables 1,2$)$. No other brain region correlated significantly with freezing during extinction recall.

\section{Fear-related cortico-amygdala IEG activation}

129S1 and C57BL/6J did not significantly differ in freezing during fear recall (129S1, $55.2 \pm 3.5 \%$; C57BL/6J, $51.6 \pm 5.2 \%$; NS). There was no significant effect of strain on the number of either c-Fos- or Zif268-positive cells in any brain region examined ( $\mathrm{Ta}$ ble 3) (all NS) after fear recall.

\section{Discussion}

The major finding of the present study was the identification of a significant and selective impairment in fear extinction in a common inbred mouse strain, 129S1/SvImJ (129S1). This phenotype was associated with abnormal activation of a key prefrontalamygdala pathway mediating fear extinction.

Our initial strain survey was the broadest conducted to date and revealed marked differences in fear extinction across inbred strains. Although not the focus of our study, we observed strain differences in the acquisition and expression of conditioned fear per se, in line with previous reports comparing various strains (Paylor et al., 1993, 1994; Fordyce et al., 1995; Caldarone et al., 1997; Owen et al., 1997; Wehner et al., 1997; Gerlai, 1998; Valentinuzzi et al., 1998; Stiedl et al., 1999; Nguyen et al., 2000; Bolivar et al., 2001; Balogh et al., 2002; Cook et al., 2002; Holmes et al., 2002; Balogh and Wehner, 2003; Bothe et al., 2005). In terms of extinction, DBA/2J, FVB/NJ, BALB/cByJ, and C57BL/6J exhibited significant within-session extinction, albeit to varying degrees. Of note, within-session extinction learning and between-session extinction recall was modest and incomplete in the reference strain, C57BL/6J, under these current test condi- tions. This rate of extinction is comparable with that seen in other laboratories using a similar $30 \mathrm{~s}$ tone massed fear conditioning protocol (Herry et al., 2006) or a fear-potentiated startle paradigm (Waddell et al., 2004), although lesser than that seen with other conditioning protocols (Siegmund et al., 2005) and other test conditions in our hands (Norcross et al., 2008).

Of the strains currently tested, the most striking extinction profile was exhibited by the 129S1 strain. 129S1 showed no apparent short-term extinction learning over $2 \times 50$ trial massed extinction sessions and no long-term extinction recall. Although A/J also showed poor within-session extinction, as previously reported (Owen et al., 1997), these mice exhibited heightened unconditioned freezing that confounded interpretation of their extinction profile. In contrast, impaired extinction in 129S1 was not an artifact of increased pain perception (assayed via hot plate and Von Frey tests) or increased fear conditioned fear per se. This was demonstrated by a lack of fear recall differences between 129S1 and C57BL/6J on a multiple tone-shock paradigms and, to circumvent potential ceiling levels of freezing, a one tone-shock paradigm. Normal fear conditioning in 129S1 is consistent with the majority of previous reports comparing C57BL/6J and various 129 substrains, including 129S1 (Owen et al., 1997; Nguyen et al., 2000; Bolivar et al., 2001; Holmes et al., 2002; Balogh and Wehner, 2003; Bothe et al., 2005; Schimanski and Nguyen, 2005). Current data also showed that impaired fear extinction deficit in 129S1 did not extend to an appetitively driven conditioned instrumental response on touchscreen-based instrumental task (Izquierdo et al., 2006b; Brigman et al., 2008). On another measure of extinction to an aversive event (CTA) 129S1 again showed poor extinction, but a low level of acquisition and an uncondi- 
Table 1. Strain differences in c-Fos expression in cortical and amygdaloid regions after extinction recall

\begin{tabular}{|c|c|c|c|c|}
\hline & \multicolumn{2}{|l|}{ Baseline } & \multicolumn{2}{|c|}{ Extinction recall } \\
\hline & 12951 & (57BL/6) & $129 S 1$ & (57BL/6J \\
\hline \multicolumn{5}{|l|}{ Cortical regions } \\
\hline M1 (1.78 mm) & $0.3 \pm 0.2$ & $0.1 \pm 0.1$ & $0.6 \pm 0.3$ & $0.4 \pm 0.2$ \\
\hline $\mathrm{M} 2(1.78 \mathrm{~mm})^{*}$ & $0.9 \pm 0.2$ & $0.8 \pm 0.4$ & $0.8 \pm 0.2$ & $0.6 \pm 0.2$ \\
\hline Cg1 (1.78 mm) & $2.0 \pm 0.3$ & $0.6 \pm 0.3$ & $9.8 \pm 1.1$ & $9.3 \pm 0.5$ \\
\hline $\operatorname{Cg} 1(1.54 \mathrm{~mm})^{*}$ & $2.3 \pm 0.3$ & $0.8 \pm 0.3$ & $9.7 \pm 0.7$ & $9.4 \pm 0.5$ \\
\hline $\operatorname{Cg} 2(1.10 \mathrm{~mm})^{*}$ & $3.1 \pm 0.5$ & $2.0 \pm 0.5$ & $12.3 \pm 0.9$ & $11.3 \pm 0.7$ \\
\hline $\operatorname{PrL}(1.78 \mathrm{~mm})^{*}$ & $1.5 \pm 0.3$ & $1.1 \pm 0.3$ & $9.3 \pm 0.8$ & $10.0 \pm 0.5$ \\
\hline $\operatorname{PrL}(1.54 \mathrm{~mm})^{*}$ & $2.0 \pm 0.3$ & $1.0 \pm 0.2$ & $10.9 \pm 0.8$ & $11.6 \pm 0.3$ \\
\hline $\mathrm{IL}(1.78 \mathrm{~mm})^{*}$ & $1.6 \pm 0.3$ & $1.6 \pm 0.3$ & $6.8 \pm 0.4$ & $11.9 \pm 0.5^{* *}$ \\
\hline $\mathrm{IL}(1.54 \mathrm{~mm})^{*}$ & $1.9 \pm 0.6$ & $2.1 \pm 0.4$ & $6.0 \pm 0.4$ & $9.7 \pm 0.7^{* *}$ \\
\hline \multicolumn{5}{|c|}{ Amygdala nuclei (all -1.58 mm) } \\
\hline $\mathrm{LA}^{*}$ & $0.9 \pm 0.3$ & $0.8 \pm 0.3$ & $2.7 \pm 0.5$ & $2.8 \pm 0.3$ \\
\hline$B L A^{*}$ & $1.0 \pm 0.4$ & $1.3 \pm 0.3$ & $2.1 \pm 0.5$ & $7.9 \pm 0.5^{* *}$ \\
\hline $\mathrm{CeA}^{*}$ & $0.8 \pm 0.3$ & $0.8 \pm 0.3$ & $5.1 \pm 0.5$ & $1.8 \pm 0.3^{* *}$ \\
\hline \multicolumn{5}{|l|}{$\operatorname{Imp} p^{a}$} \\
\hline \multicolumn{5}{|l|}{$\| p^{a}$} \\
\hline MePD* & $1.4 \pm 0.5$ & $1.0 \pm 0.4$ & $5.6 \pm 0.5$ & $6.7 \pm 0.5$ \\
\hline $\mathrm{MePV}^{*}$ & $4.8 \pm 0.5$ & $4.8 \pm 0.3$ & $8.3 \pm 0.5$ & $8.3 \pm 0.4$ \\
\hline $\mathrm{AC} 0$ & $5.9 \pm 1.1$ & $6.3 \pm 0.7$ & $10.6 \pm 0.6$ & $10.0 \pm 0.6$ \\
\hline $\mathrm{PLC}{ }^{*}$ & $2.9 \pm 0.6$ & $3.3 \pm 0.9$ & $8.1 \pm 0.7$ & $7.4 \pm 0.4$ \\
\hline
\end{tabular}

12951 mice had fewer c-Fos-positive cells in IL and BLA and more c-Fos-positive cells in CeA than C57BL/6J after extinction recall. No other cortical or amygdaloid region examined differed between strains ( $n=8$ per strain). C $S$ minus baseline c-Fos expression did not differ between strains baseline in any brain region examined ( $n=4$ per strain). Data are mean \pm SEM c-Fos-positive cells per $0.01 \mathrm{~mm}^{2}$. M1, Primary motor; M2, secondary motor; $(\mathrm{cg} 1$, cingulate area 1; Cg2, cingulate area 2; PrL, prelimbic; MePD, medial, posterodorsal; MePV, medial, posteroventral; ACo, anterior cortical; PLC0, posterolateral cortical. ${ }^{a}$ No detectable expression.

${ }^{*} p<0.01$, extinction recall versus baseline; ${ }^{* *} p<0.01$, (57BL/6J versus $129 \mathrm{~S} 1 /$ same condition.

tioned aversion to saccharin prevented clear interpretation of CTA extinction. Together, these data demonstrate a selective deficit in the formation of fear extinction memory in 129S1.

Fear extinction in $129 \mathrm{~S} 1$ was not improved by providing additional massed extinction trials. Nor was it facilitated by treatment with the partial NMDAR agonist D-cycloserine. This differs from the extinction facilitating effects of D-cycloserine in conditioned freezing or fear-potentiated startle paradigms in C57BL/6J mice (Tomilenko and Dubrovina, 2007; current study), rats (Walker et al., 2002; Richardson et al., 2004), as well human phobics (Ressler et al., 2004). The inefficacy of D-cycloserine in 129S1 could further reflect usually strong resistance to extinction in this strain and/or different molecular mechanisms driving the behavior across different mouse stains. In this context, yohimbine, a compound with antagonist properties at $\alpha 2$ adrenoreceptors among other effects, significantly improved long-term extinction in $129 \mathrm{~S} 1$, as previously seen in rats and C57BL/6J mice (Cain et al., 2004; Morris and Bouton, 2007). This demonstrates that impaired extinction in $129 \mathrm{~S} 1$ can be at least partially reversed, although the molecular mechanisms involved remain to be determined.

Deficient fear extinction in 129S1 was associated with a striking alteration in the activation profile of a key prefrontalamygdala circuit mediating fear extinction. This was assayed via expression of the IEG c-Fos, a surrogate marker for neuronal activation (Singewald, 2007) and Zif268, an IEG that acts as a transcription factor subserving fear memory (re)consolidation (Davis et al., 2003; Lee et al., 2004). Consistent with the absence of behavioral differences after fear recall or nonconditioned baseline, IEG activation in IL (or any region examined) did not differ between strains. In contrast, C57BL/6J showed significantly greater extinction-related IEG activation than 129S1 in IL, and IL activation showed a high correlation $(-0.86)$ with freezing during initial extinction recall. This suggests an extinction-related failure to recruit IL in 129S1 mice, consistent with the important role ascribed to IL in rodent extinction (Herry and Mons, 2004; Quirk et al., 2006) and homologous regions in human extinction (Phelps et al., 2004; Kalisch et al., 2006; Milad et al., 2007).

Impaired fear extinction in 129S1 was not associated with blunted IL activation alone, but instead reflected a circuit level failure. 129S1 showed lesser IEG expression than C57BL/6J in BLA (but not medial or cortical amygdala subnuclei) after extinction. They also showed lesser induction of Zif268, but not c-Fos, in LA. Although the functional significance of this subnuclei dissociation between the two IEGs is not clear, it is in full agreement with the finding of low Zif268, not c-Fos, expression in the LA of poor extinguishing C57BL/6J mice after extinction recall (Herry and Mons, 2004) (see also Santini et al., 2004). More generally, although LA and BLA drive conditioned fear via CeA, the contribution of these regions to extinction learning is only now being uncovered. For example, whereas BLA lesions do not affect extinction learning (Sotres-Bayon et al., 2004; Anglada-Figueroa and Quirk, 2005), a subclass of LA/BLA neurons are active and depotentiated during extinction (Repa et al., 2001; Kim et al., 2007b). Furthermore, blockade of NMDARs or MAPK signaling in BLA impairs fear extinction in rats and C57BL/6J mice (Herry et al., 2006; Sotres-Bayon et al., 2007), and depotentiation of conditioning-induced long-term potentiation in BLA predicts successful extinction (for review, see Barad et al., 2006). Together with current findings, this supports a role for LA/BLA, likely working in concert with IL, in the acquisition and expression of fear extinction (see Note added in proof). As such, possible abnormalities in BLA neuronal depotentiation (BLA longterm potentiation appears normal in these mice) (Schimanski and Nguyen, 2005) or signaling in 129S1 will be an interesting avenue for future study.

The ITC cell masses of the amygdala are posited to be another important component of the extinction circuit (Paré et al., 2004). These GABAergic neurons serve as an intra-amygdala relay station exerting feedforward inhibition over CeA amygdala output (Paré et al., 2004) (see Note added in proof). BLA and IL send projections to the ITC cell masses (McDonald et al., 1996; Royer et al., 1999; Vertes, 2002; Berretta et al., 2005). In the rat, IL stimulation increases ITC c-Fos expression (Berretta et al., 2005) and produced an associated inhibition of CeA neurons (Quirk et al., 2003). In our mouse extinction paradigm, extinction was associated with strong Zif268 expression in the Imp and Ilp ITC masses, and this correlated with levels of freezing during extinction. To our knowledge, this is the first demonstration of extinction induced ITC activation. However, unlike Berretta et al. (2005) had, we did not see ITC c-Fos expression, possibly because of relatively weaker IL stimulation by extinction than chemical stimulation, or a species difference. Zif268 expression in ITCs differed between strains. Curiously, however, there was relatively greater activation of Imp (but not Ilp) in 129S1 than C57BL/6J. Moreover, and as expected given the high fear during extinction recall in 129S1, CeA c-Fos expression was markedly higher in these mice relative to $\mathrm{C} 57 \mathrm{BL} / 6 \mathrm{~J}$. As such, the strain differences in 


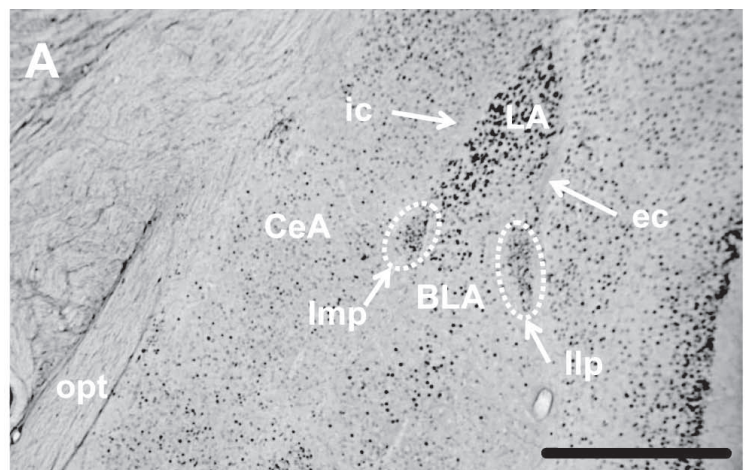

B

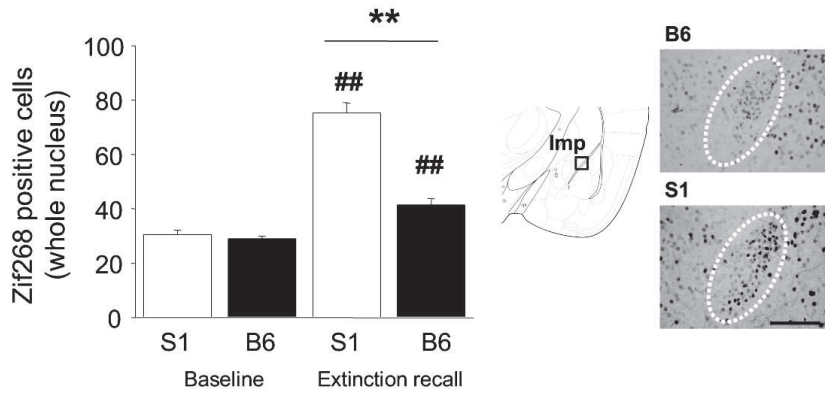

C

O $B 6 \Delta \mathrm{S1}$

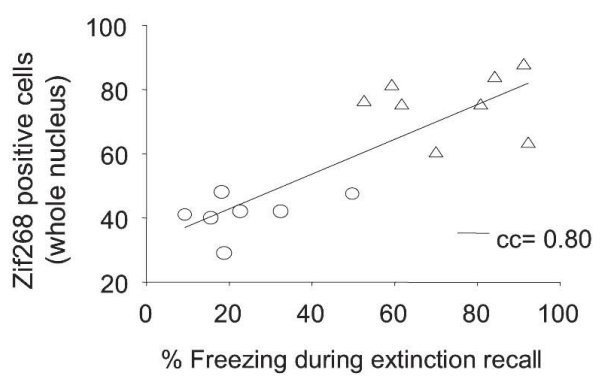

Figure 7. Zif268-positive cells identified in the ITC masses of the amygdala after extinction recall. Representative illustration of anatomical definition of ITC mass nuclei labeled with Zif268 immunoreactivity. A, Anatomical definition of Zif268-expressing medial paracapsular ITC mass (Imp) and lateral paracapsular ITC mass (IIp). Scale bar, $500 \mu \mathrm{m} . \boldsymbol{B}, 12951$ (S1) mice showed a greater increase (relative to CS minus baseline) in Zif268-positive cells in Imp (but not Ilp) (Table 1) than C57BL/6J (B6) after extinction recall. Scale bar, $100 \mu \mathrm{m}$. C, Across strains, the number of Zif268-positive cells in Imp was positively correlated with freezing during extinction recall. $n=$ 7-8/strain for extinction recall; $n=4 /$ strain for baseline. cc, Correlation coefficient; ic, internal capsule; LA, lateral nucleus; ec, external capsule; CeA, central nucleus; BLA, basolateral nucleus; opt, optic tract; Imp, medial paracapsular nucleus; Ilp, lateral paracapsular nucleus. ${ }^{* *} p<0.01$ 12951 versus $B 6 ;{ }^{\# \#} p<0.01$ versus baseline.

ITC recruitment are not easily reconciled with the aforementioned circuit model of extinction and raise the question of why CeA activity in 129S1 is high in the face of both high ITC and low BLA input. One possibility is that there may be other sources of excitatory input to CeA that could be functionally aberrant in $129 S 1$ mice (e.g., from posterior thalamic nucleus). Another possibility is that there is a network of functionally diverse ITC cells, some signaling fear and others inhibiting $\mathrm{CeA}$, and we are sampling the former subpopulation. [For further discussion of these possibilities, see Paré et al. (2004)]. Clearly, additional studies are needed to fully elucidate the precise nature of the strain differences in extinction-related cortico-amygdala activation. Not- withstanding, the main conclusion from the current data are that impaired extinction in $129 \mathrm{~S} 1$ is associated with a failure to properly recruit prefrontal and amygdala circuitry mediating this behavior.

In summary, through a strain survey, we identified an inbred mouse strain, 129S1, with a marked deficit in fear extinction. The extinction deficit in this strain was dissociable from fear conditioning and extinction of an instrumental appetitive behavior, both of which were normal in 129S1. 129S1 were resistant to the extinction facilitating effects of extended massed training and treatment with D-cycloserine, but yohimbine treatment improved long-term extinction. Analysis of neural activation after extinction recall revealed hypoactivation of IL and BLA, differential activation of the ITCs, and hyperactivation of CeA in 129S1 relative to $\mathrm{C} 57 \mathrm{BL} / 6 \mathrm{~J}$. Although previous studies have produced fear extinction deficits by neuroanatomical lesions, gene mutations, and selected breeding, the 129S1 mouse is a naturally occurring example of impaired fear extinction and corticoamygdala dysfunction in an animal model. This provides an opportunity to study sources of genetic variation driving differences in extinction. More generally, given the increasing convergence of rodent and human studies of emotional disorders and extinction in particular (Holmes and Hariri, 2003; Phelps et al., 2004; Milad et al., 2006; Cryan and Slattery, 2007; Ji and Maren, 2007), 129S1 mice could provide a useful model for studying the pathophysiology and therapeutic alleviation of impaired fear extinction in anxiety disorders such as phobias and posttraumatic stress disorder.

Note added in proof. At the time the current article was going to press, two important studies were published further describing the role of the amygdala and ITC masses in rodent fear extinction (Herry et al., 2008; Likhtik et al., 2008).

\section{References}

Anglada-Figueroa D, Quirk GJ (2005) Lesions of the basal amygdala block expression of conditioned fear but not extinction. J Neurosci 25:9680-9685.

Balogh SA, Wehner JM (2003) Inbred mouse strain differences in the establishment of long-term fear memory. Behav Brain Res 140:97-106.

Balogh SA, Radcliffe RA, Logue SF, Wehner JM (2002) Contextual and cued fear conditioning in C57BL/6J and DBA/2J mice: context discrimination and the effects of retention interval. Behav Neurosci 116:947-957.

Barad M, Gean PW, Lutz B (2006) The role of the amygdala in the extinction of conditioned fear. Biol Psychiatry 60:322-328.

Berlau DJ, McGaugh JL (2006) Enhancement of extinction memory consolidation: the role of the noradrenergic and GABAergic systems within the basolateral amygdala. Neurobiol Learn Mem 86:123-132.

Berretta S, Pantazopoulos H, Caldera M, Pantazopoulos P, Paré D (2005) Infralimbic cortex activation increases c-Fos expression in intercalated neurons of the amygdala. Neuroscience 132:943-953.

Blanchard RJ, Blanchard DC (1969) Crouching as an index of fear. J Comp Physiol Psychol 67:370-375.

Bolivar VJ, Pooler O, Flaherty L (2001) Inbred strain variation in contextual and cued fear conditioning behavior. Mamm Genome 12:651-656.

Bothe GW, Bolivar VJ, Vedder MJ, Geistfeld JG (2005) Behavioral differences among fourteen inbred mouse strains commonly used as disease models. Comp Med 55:326-334.

Boyce-Rustay JM, Holmes A (2006) Genetic inactivation of the NMDA receptor NR2A subunit has anxiolytic- and antidepressant-like effects in mice. Neuropsychopharmacology 31:2405-2414.

Brigman JL, Feyder M, Saksida LM, Bussey TJ, Mishina M, Holmes A (2008) Impaired discrimination learning in mice lacking the NMDA receptor NR2A subunit. Learn Mem 15:50-54.

Cain CK, Blouin AM, Barad M (2002) L-type voltage-gated calcium channels are required for extinction, but not for acquisition or expression, of conditional fear in mice. J Neurosci 22:9113-9121. 
Table 2. Strain differences in Zif268 expression in cortical and amygdaloid regions after extinction recall

\begin{tabular}{|c|c|c|c|c|}
\hline & \multicolumn{2}{|l|}{ Baseline } & \multicolumn{2}{|c|}{ Extinction recall } \\
\hline & 12951 & (57BL/6J & $129 S 1$ & (57BL/6J \\
\hline \multicolumn{5}{|l|}{ Cortical regions } \\
\hline M1 (1.78 mm) & $12.3 \pm 0.8$ & $11.9 \pm 0.5$ & $14.1 \pm 0.5$ & $13.6 \pm 0.7$ \\
\hline $\mathrm{M} 2(1.78 \mathrm{~mm})^{*}$ & $12.6 \pm 0.7$ & $12.2 \pm 0.7$ & $22.8 \pm 0.6$ & $23.9 \pm 0.8$ \\
\hline $\mathrm{Cg} 1(1.78 \mathrm{~mm})$ & $14.3 \pm 0.6$ & $13.6 \pm 0.9$ & $22.0 \pm 0.8$ & $23.6 \pm 0.8$ \\
\hline $\operatorname{Cg} 1(1.54 \mathrm{~mm})^{*}$ & $13.3 \pm 0.8$ & $14.4 \pm 0.3$ & $13.8 \pm 0.6$ & $13.9 \pm 0,6$ \\
\hline $\operatorname{Cg} 2(1.10 \mathrm{~mm})^{*}$ & $17.4 \pm 1.6$ & $16.5 \pm 0.9$ & $20.7 \pm 0.8$ & $20.1 \pm 0.3$ \\
\hline $\operatorname{PrL}(1.78 \mathrm{~mm})^{*}$ & $10.8 \pm 0.6$ & $11.3 \pm 0.9$ & $21.1 \pm 1.2$ & $23.1 \pm 0.8$ \\
\hline $\operatorname{PrL}(1.54 \mathrm{~mm})^{*}$ & $11.3 \pm 0.6$ & $13.1 \pm 0.6$ & $23.1 \pm 1.1$ & $22.3 \pm 0.6$ \\
\hline IL $(1.78 \mathrm{~mm})^{*}$ & $6.8 \pm 0.5$ & $5.8 \pm 0.5$ & $9.7 \pm 0.6$ & $16.6 \pm 0.7^{* *}$ \\
\hline IL $(1.54 \mathrm{~mm})^{*}$ & $7.3 \pm 0.6$ & $6.1 \pm 0.5$ & $12.9 \pm 0.9$ & $21.2 \pm 1.3^{* *}$ \\
\hline \multicolumn{5}{|c|}{ Amygdala nuclei (all $-1.58 \mathrm{~mm}$ ) } \\
\hline$L A^{*}$ & $6.5 \pm 0.8$ & $6.0 \pm 0.6$ & $13.6 \pm 0.9$ & $20.6 \pm 0.8^{* *}$ \\
\hline$B L A^{*}$ & $3.9 \pm 0.5$ & $4.3 \pm 0.2$ & $7.6 \pm 1.3$ & $13.6 \pm 0.6^{* *}$ \\
\hline $\mathrm{CeA}^{*}$ & $1.5 \pm 0.3$ & $1.7 \pm 0.6$ & $3.1 \pm 0.1$ & $2.9 \pm 0.4$ \\
\hline $\operatorname{Imp}^{a}$ & $30.5 \pm 1.7$ & $29.0 \pm 0.9$ & $75.1 \pm 3.9$ & $41.4 \pm 2.4^{* *}$ \\
\hline$\| p^{a *}$ & $21.1 \pm 5.1$ & $18.5 \pm 1.8$ & $41.3 \pm 3.9$ & $41.2 \pm 2.6$ \\
\hline MePD* & $2.9 \pm 0.4$ & $2.7 \pm 0.6$ & $9.8 \pm 0.6$ & $10.4 \pm 0.5$ \\
\hline $\mathrm{MePV}^{*}$ & $10.8 \pm 0.8$ & $10.5 \pm 0.8$ & $13.8 \pm 1.2$ & $13.8 \pm 0.9$ \\
\hline $\mathrm{ACO}$ & $11.0 \pm 1.1$ & $10.8 \pm 0.9$ & $11.3 \pm 0.9$ & $11.8 \pm 0.8$ \\
\hline$P L C 0^{*}$ & $9.4 \pm 1.1$ & $10.3 \pm 1.2$ & $16.8 \pm 0.6$ & $18.0 \pm 1.0$ \\
\hline
\end{tabular}

12951 mice had fewer Zif268-positive cells in IL, LA, BLA, and Imp than C57BL/6J after extinction recall. No other cortical or amygdaloid region examined differed between strains ( $n=7-8$ per strain). Baseline Zif268 expression did not differ between strains in any brain region examined ( $n=4$ per strain). Data are mean \pm SEM Zif268-positive cells per $0.01 \mathrm{~mm}^{2}$. For each region, the abbreviation and plane of section relative to bregma is given in parentheses. M1, Primary motor; $\mathrm{M2}$, secondary motor; Cg1, cingulate area 1; Cg2, cingulate area 2; PrL, prelimbic; MePD, medial, posterodorsal; MePV, medial, posteroventral; ACo, anterior cortical; PLCo, posterolateral cortical.

${ }^{a}$ Whole nucleus counted.

${ }^{*} p<0.01$, extinction recall versus CS minus baseline; ${ }^{* *} p<0.01$, C57BL/6J versus 129S1/same condition.

Table 3. Absence of strain differences in c-Fos or Zif268 expression in cortical and amygdaloid regions after fear recall

\begin{tabular}{|c|c|c|c|c|}
\hline & \multicolumn{2}{|l|}{ c-Fos } & \multicolumn{2}{|l|}{ Zif268 } \\
\hline & 12951 & C57BL/6J & 12951 & (57BL/6J \\
\hline \multicolumn{5}{|l|}{ Cortical regions } \\
\hline M1 (1.78 mm) & $0.1 \pm 0.1$ & $0.1 \pm 0.1$ & $25.8 \pm 1.0$ & $26.0 \pm 1.0$ \\
\hline $\mathrm{M} 2(1.78 \mathrm{~mm})$ & $4.9 \pm 0.4$ & $4.6 \pm 0.4$ & $28.9 \pm 1.0$ & $27.9 \pm 1.2$ \\
\hline $\operatorname{Cg} 1(1.78 \mathrm{~mm})$ & $7.5 \pm 0.7$ & $7.6 \pm 0.6$ & $28.6 \pm 0.9$ & $29.1 \pm 0.7$ \\
\hline $\operatorname{Cg} 1(1.54 \mathrm{~mm})$ & $9.5 \pm 0.7$ & $9.4 \pm 0.6$ & $29.3 \pm 1.1$ & $30.2 \pm 0.8$ \\
\hline $\operatorname{Cg} 2(1.10 \mathrm{~mm})$ & $13.0 \pm 0.8$ & $12.5 \pm 0.4$ & $36.5 \pm 1.3$ & $35.9 \pm 0.7$ \\
\hline $\operatorname{PrL}(1.78 \mathrm{~mm})$ & $11.3 \pm 0.9$ & $11.6 \pm 0.6$ & $27.4 \pm 0.7$ & $27.7 \pm 1.0$ \\
\hline $\operatorname{PrL}(1.54 \mathrm{~mm})$ & $13.0 \pm 1.0$ & $13.7 \pm 0.7$ & $31.4 \pm 1.3$ & $33.6 \pm 1.0$ \\
\hline $\mathrm{IL}(1.78 \mathrm{~mm})$ & $2.9 \pm 0.5$ & $2.4 \pm 0.4$ & $9.1 \pm 0.5$ & $9.7 \pm 0.6$ \\
\hline IL (1.54 mm) & $4.2 \pm 0.3$ & $3.8 \pm 0.3$ & $11.0 \pm 0.7$ & $11.6 \pm 0.6$ \\
\hline \multicolumn{5}{|c|}{ Amygdala nuclei (all $-1.58 \mathrm{~mm}$ ) } \\
\hline LA & $2.7 \pm 0.3$ & $2.5 \pm 0.3$ & $32.4 \pm 1.3$ & $32.0 \pm 0.7$ \\
\hline BLA & $7.6 \pm 0.5$ & $6.6 \pm 0.3$ & $15.2 \pm 0.8$ & $14.1 \pm 0.8$ \\
\hline CeA & $4.9 \pm 0.4$ & $5.1 \pm 0.3$ & $8.0 \pm 0.3$ & $8.2 \pm 0.4$ \\
\hline $\operatorname{Imp}^{a}$ & ND & ND & $39.0 \pm 1.2$ & $36.9 \pm 1.2$ \\
\hline$\| p^{a}$ & ND & ND & $38.4 \pm 1.1$ & $37.2 \pm 1.1$ \\
\hline MePD & $4.8 \pm 0.6$ & $4.9 \pm 0.5$ & $15.0 \pm 0.4$ & $14.2 \pm 0.6$ \\
\hline MePV & $8.8 \pm 0.5$ & $8.0 \pm 0.4$ & $22.2 \pm 1.1$ & $19.6 \pm 0.5$ \\
\hline $\mathrm{ACO}$ & $9.4 \pm 0.8$ & $8.6 \pm 0.6$ & $26.2 \pm 0.9$ & $26.3 \pm 1.3$ \\
\hline PLCo & $10.9 \pm 1.1$ & $10.6 \pm 0.8$ & $27.4 \pm 1.3$ & $28.2 \pm 1.1$ \\
\hline
\end{tabular}

12951 and C57BL/6J mice did not differ in c-Fos- or Zif268-positive cells in any brain region examined ( $n=10 /$ strain). Data are mean \pm SEM c-Fos- and Zif268-positive cells per $0.01 \mathrm{~mm}^{2}$. For each region, the abbreviation and plane of section relative to bregma is given in parentheses. M1, Primary motor; M2, secondary motor; $\mathrm{Cg} 1$, cingulate area 1; $\mathrm{Cg} 2$, cingulate area 2; PrL, prelimbic; MePD, medial, posterodorsal; MePV, medial, posteroventral; $\mathrm{AC} 0$, anterior cortical; PLCo, posterolateral cortical; ND, no detectable expression.

${ }^{a}$ Whole nucleus counted

Cain CK, Blouin AM, Barad M (2004) Adrenergic transmission facilitates extinction of conditional fear in mice. Learn Mem 11:179-187.

Caldarone B, Saavedra C, Tartaglia K, Wehner JM, Dudek BC, Flaherty L (1997) Quantitative trait loci analysis affecting contextual conditioning in mice. Nat Genet 17:335-337.

Chen X, Garelick MG, Wang H, Lil V, Athos J, Storm DR (2005) PI3 kinase signaling is required for retrieval and extinction of contextual memory. Nat Neurosci 8:925-931.
Chhatwal JP, Davis M, Maguschak KA, Ressler KJ (2005) Enhancing cannabinoid neurotransmission augments the extinction of conditioned fear. Neuropsychopharmacology 30:516-524.

Cook MN, Bolivar VJ, McFadyen MP, Flaherty L (2002) Behavioral differences among 129 substrains: implications for knockout and transgenic mice. Behav Neurosci 116:600-611.

Cryan JF, Holmes A (2005) The ascent of mouse: advances in modelling human depression and anxiety. Nat Rev Drug Discov 4:775-790.

Cryan JF, Slattery DA (2007) Animal models of mood disorders: recent developments. Curr Opin Psychiatry 20:1-7.

Davis M, Ressler K, Rothbaum BO, Richardson R (2006) Effects of D-cycloserine on extinction: translation from preclinical to clinical work. Biol Psychiatry 60:369-375.

Davis S, Bozon B, Laroche S (2003) How necessary is the activation of the immediate early gene zif268 in synaptic plasticity and learning? Behav Brain Res 142:17-30.

Falls WA, Carlson S, Turner JG, Willott JF (1997) Fear-potentiated startle in two strains of inbred mice. Behav Neurosci 111:855-861.

Fendt M, Schmid S, Thakker DR, Jacobson LH, Yamamoto R, Mitsukawa K, Maier R, Natt F, Husken D, Kelly PH, McAllister KH, Hoyer D, van der Putten H, Cryan JF, Flor PJ (2008) mGluR7 facilitates extinction of aversive memories and controls amygdala plasticity. Mol Psychiatry, in press.

Fordyce DE, Clark VJ, Paylor R, Wehner JM (1995) Enhancement of hippocampallymediated learning and protein kinase $\mathrm{C}$ activity by oxiracetam in learning-impaired DBA/2 mice. Brain Res 672:170-176.

Geracitano R, Kaufmann WA, Szabo G, Ferraguti F, Capogna M (2007) Synaptic heterogeneity between mouse paracapsular intercalated neurons of the amygdala. J Physiol 585:117-134.

Gerlai R (1998) Contextual learning and cue association in fear conditioning in mice: a strain comparison and a lesion study. Behav Brain Res 95:191-203.

Hasnie FS, Wallace VC, Hefner K, Holmes A, Rice AS (2007) Mechanical and cold hypersensitivity in nerve-injured C57BL/6J mice is not associated with fear-avoidance- and depression-related behaviour. $\mathrm{Br} \mathrm{J}$ Anaesth 98:816-822.

Hawasli AH, Benavides DR, Nguyen C, Kansy JW, Hayashi K, Chambon P, Greengard P, Powell CM, Cooper DC, Bibb JA (2007) Cyclindependent kinase 5 governs learning and synaptic plasticity via control of NMDAR degradation. Nat Neurosci 10:880-886.

Herry C, Mons N (2004) Resistance to extinction is associated with impaired immediate early gene induction in medial prefrontal cortex and amygdala. Eur J Neurosci 20:781-790.

Herry C, Trifilieff P, Micheau J, Lüthi A, Mons N (2006) Extinction of auditory fear conditioning requires MAPK/ERK activation in the basolateral amygdala. Eur J Neurosci 24:261-269.

Herry C, Ciocchi S, Senn V, Demmou L, Müller C, Lüthi A (2008) Switching on and off fear by distinct neuronal circuits. Nature, in press.

Holmes A, Hariri AR (2003) The serotonin transporter gene-linked polymorphism and negative emotionality: placing single gene effects in the context of genetic background and environment. Genes Brain Behav 2:332-335. 
Holmes A, Wrenn CC, Harris AP, Thayer KE, Crawley JN (2002) Behavioral profiles of inbred strains on novel olfactory, spatial and emotional tests for reference memory in mice. Genes Brain Behav 1:55-69.

Isiegas C, Park A, Kandel ER, Abel T, Lattal KM (2006) Transgenic inhibition of neuronal protein kinase A activity facilitates fear extinction. J Neurosci 26:12700-12707.

Izquierdo A, Wellman CL, Holmes A (2006a) Brief uncontrollable stress causes dendritic retraction in infralimbic cortex and resistance to fear extinction in mice. J Neurosci 26:5733-5738.

Izquierdo A, Wiedholz LM, Millstein RA, Yang RJ, Bussey TJ, Saksida LM, Holmes A (2006b) Genetic and dopaminergic modulation of reversal learning in a touchscreen-based operant procedure for mice. Behav Brain Res 171:181-188.

Jacobson LH, Kelly PH, Bettler B, Kaupmann K, Cryan JF (2006) GABA B(1) receptor isoforms differentially mediate the acquisition and extinction of aversive taste memories. J Neurosci 26:8800-8803.

Ji J, Maren S (2007) Hippocampal involvement in contextual modulation of fear extinction. Hippocampus 17:749-758.

Kalisch R, Korenfeld E, Stephan KE, Weiskopf N, Seymour B, Dolan RJ (2006) Context-dependent human extinction memory is mediated by a ventromedial prefrontal and hippocampal network. J Neurosci 26:9503-9511.

Kamprath K, Wotjak CT (2004) Nonassociative learning processes determine expression and extinction of conditioned fear in mice. Learn Mem 11:770-786.

Kim J, Lee S, Park H, Song B, Hong I, Geum D, Shin K, Choi S (2007a) Blockade of amygdala metabotropic glutamate receptor subtype 1 impairs fear extinction. Biochem Biophys Res Commun 355:188-193.

Kim J, Lee S, Park K, Hong I, Song B, Son G, Park H, Kim WR, Park E, Choe HK, Kim H, Lee C, Sun W, Kim K, Shin KS, Choi S (2007b) Amygdala depotentiation and fear extinction. Proc Natl Acad Sci USA 104:20955-20960.

Lattal KM, Barrett RM, Wood MA (2007) Systemic or intrahippocampal delivery of histone deacetylase inhibitors facilitates fear extinction. Behav Neurosci 121:1125-1131.

Lee JL, Everitt BJ, Thomas KL (2004) Independent cellular processes for hippocampal memory consolidation and reconsolidation. Science 304:839-843.

Likhtik E, Popa D, Apergis-Schoute J, Fidacaro GA, Paré D (2008) Amygdala intercalated neurons are required for expression of fear extinction. Nature, in press.

Lin CH, Yeh SH, Leu TH, Chang WC, Wang ST, Gean PW (2003a) Identification of calcineurin as a key signal in the extinction of fear memory. J Neurosci 23:1574-1579.

Lin CH, Yeh SH, Lu HY, Gean PW (2003b) The similarities and diversities of signal pathways leading to consolidation of conditioning and consolidation of extinction of fear memory. J Neurosci 23:8310-8317.

Lu KT, Walker DL, Davis M (2001) Mitogen-activated protein kinase cascade in the basolateral nucleus of amygdala is involved in extinction of fear-potentiated startle. J Neurosci 21:RC162(1-5).

Maren S, Quirk GJ (2004) Neuronal signalling of fear memory. Nat Rev Neurosci 5:844-852.

Marowsky A, Yanagawa Y, Obata K, Vogt KE (2005) A specialized subclass of interneurons mediates dopaminergic facilitation of amygdala function. Neuron 48:1025-1037.

Marsicano G, Wotjak CT, Azad SC, Bisogno T, Rammes G, Cascio MG, Hermann H, Tang J, Hofmann C, Zieglgänsberger W, Di Marzo V, Lutz B (2002) The endogenous cannabinoid system controls extinction of aversive memories. Nature 418:530-534.

McCaughran JA Jr, Bell J 3rd, Hitzemann RJ (2000) Fear-potentiated startle response in mice: genetic analysis of the $\mathrm{C} 57 \mathrm{BL} / 6 \mathrm{~J}$ and DBA/2J intercross. Pharmacol Biochem Behav 65:301-312.

McDonald AJ, Mascagni F, Guo L (1996) Projections of the medial and lateral prefrontal cortices to the amygdala: a Phaseolus vulgaris leucoagglutinin study in the rat. Neuroscience 71:55-75.

Milad MR, Rauch SL, Pitman RK, Quirk GJ (2006) Fear extinction in rats: implications for human brain imaging and anxiety disorders. Biol Psychol 73:61-71.

Milad MR, Wright CI, Orr SP, Pitman RK, Quirk GJ, Rauch SL (2007) Recall of fear extinction in humans activates the ventromedial prefrontal cortex and hippocampus in concert. Biol Psychiatry 62:446-454.
Millhouse OE (1986) The intercalated cells of the amygdala. J Comp Neurol 247:246-271.

Morris RW, Bouton ME (2007) The effect of yohimbine on the extinction of conditioned fear: a role for context. Behav Neurosci 121:501-514.

Myers KM, Davis M (2007) Mechanisms of fear extinction. Mol Psychiatry 12:120-150.

Nguyen PV, Abel T, Kandel ER, Bourtchouladze R (2000) Strain-dependent differences in LTP and hippocampus-dependent memory in inbred mice. Learn Mem 7:170-179.

Norcross M, Poonam M, Enoch AJ, Karlsson RM, Brigman JL, Cameron HA, Harvey-White J, Holmes A (2008) Effects of adolescent fluoxetine treatment on fear-, anxiety- or stress-related behaviors in $\mathrm{C} 57 \mathrm{BL} / 6 \mathrm{~J}$ or BALB/cJ mice. Psychopharmacology, in press.

Ouyang M, Thomas SA (2005) A requirement for memory retrieval during and after long-term extinction learning. Proc Natl Acad Sci U S A 102:9347-9352.

Owen EH, Logue SF, Rasmussen DL, Wehner JM (1997) Assessment of learning by the Morris water task and fear conditioning in inbred mouse strains and F1 hybrids: implications of genetic background for single gene mutations and quantitative trait loci analyses. Neuroscience 80:1087-1099.

Paré D, Quirk GJ, Ledoux JE (2004) New vistas on amygdala networks in conditioned fear. J Neurophysiol 92:1-9.

Pavlov IP (1927) Conditioned reflexes. London: Oxford UP.

Paxinos KBJ, Franklin G (2001) The mouse brain in stereotaxic coordinates, Ed 2. London: Academic.

Paylor R, Baskall L, Wehner JM (1993) Behavioral dissociations between C57BL/6 and DBA/2 mice on learning and memory tasks: a hippocampal dysfunction hypothesis. Psychobiology 21:11-26.

Paylor R, Tracy R, Wehner J, Rudy JW (1994) DBA/2 and C57BL/6 mice differ in contextual fear but not auditory fear conditioning. Behav Neurosci 108:810-817.

Phelps EA, Delgado MR, Nearing KI, LeDoux JE (2004) Extinction learning in humans: role of the amygdala and vmPFC. Neuron 43:897-905.

Ponnusamy R, Nissim HA, Barad M (2005) Systemic blockade of D2-like dopamine receptors facilitates extinction of conditioned fear in mice. Learn Mem 12:399-406.

Quirk GJ, Beer JS (2006) Prefrontal involvement in the regulation of emotion: convergence of rat and human studies. Curr Opin Neurobiol 16:723-727.

Quirk GJ, Mueller D (2007) Neural mechanisms of extinction learning and retrieval. Neuropsychopharmacology 33:56-72.

Quirk GJ, Likhtik E, Pelletier JG, Paré D (2003) Stimulation of medial prefrontal cortex decreases the responsiveness of central amygdala output neurons. J Neurosci 23:8800-8807.

Quirk GJ, Garcia R, Gonzalez-Lima F (2006) Prefrontal mechanisms in extinction of conditioned fear. Biol Psychiatry 60:337-343.

Radulovic J, Kammermeier J, Spiess J (1998) Generalization of fear responses in C57BL/6N mice subjected to one-trial foreground contextual fear conditioning. Behav Brain Res 95:179-189.

Repa JC, Muller J, Apergis J, Desrochers TM, Zhou Y, LeDoux JE (2001) Two different lateral amygdala cell populations contribute to the initiation and storage of memory. Nat Neurosci 4:724-731.

Ressler KJ, Rothbaum BO, Tannenbaum L, Anderson P, Graap K, Zimand E, Hodges L, Davis M (2004) Cognitive enhancers as adjuncts to psychotherapy: use of D-cycloserine in phobic individuals to facilitate extinction of fear. Arch Gen Psychiatry 61:1136-1144.

Richardson R, Ledgerwood L, Cranney J (2004) Facilitation of fear extinction by D-cycloserine: theoretical and clinical implications. Learn Mem 11:510-516.

Royer S, Martina M, Paré D (1999) An inhibitory interface gates impulse traffic between the input and output stations of the amygdala. J Neurosci 19:10575-10583.

Sananbenesi F, Fischer A, Wang X, Schrick C, Neve R, Radulovic J, Tsai LH (2007) A hippocampal Cdk5 pathway regulates extinction of contextual fear. Nat Neurosci 10:1012-1019.

Santini E, Ge H, Ren K, Peña de Ortiz S, Quirk GJ (2004) Consolidation of fear extinction requires protein synthesis in the medial prefrontal cortex. J Neurosci 24:5704-5710.

Schimanski LA, Nguyen PV (2005) Mouse models of impaired fear memory exhibit deficits in amygdalar LTP. Hippocampus 15:502-517.

Siegmund A, Langnaese K, Wotjak CT (2005) Differences in extinction of 
conditioned fear in C57BL/6 substrains are unrelated to expression of alpha-synuclein. Behav Brain Res 157:291-298.

Singewald N (2007) Altered brain activity processing in high-anxiety rodents revealed by challenge paradigms and functional mapping. Neurosci Biobehav Rev 31:18-40.

Singewald N, Salchner P, Sharp T (2003) Induction of c-Fos expression in specific areas of the fear circuitry in rat forebrain by anxiogenic drugs. Biol Psychiatry 53:275-283.

Sotres-Bayon F, Bush DE, LeDoux JE (2004) Emotional perseveration: an update on prefrontal-amygdala interactions in fear extinction. Learn Mem 11:525-535.

Sotres-Bayon F, Bush DE, LeDoux JE (2007) Acquisition of fear extinction requires activation of NR2B-containing NMDA receptors in the lateral amygdala. Neuropsychopharmacology 32:1929-1940.

Stiedl O, Radulovic J, Lohmann R, Birkenfeld K, Palve M, Kammermeier J, Sananbenesi F, Spiess J (1999) Strain and substrain differences in context- and tone-dependent fear conditioning of inbred mice. Behav Brain Res 104:1-12.

Tomilenko RA, Dubrovina NI (2007) Effects of activation and blockade of NMDA receptors on the extinction of a conditioned passive avoidance response in mice with different levels of anxiety. Neurosci Behav Physiol 37:509-515.

Valentinuzzi VS, Kolker DE, Vitaterna MH, Shimomura K, Whiteley A, LowZeddies S, Turek FW, Ferrari EA, Paylor R, Takahashi JS (1998) Automated measurement of mouse freezing behavior and its use for quantitative trait locus analysis of contextual fear conditioning in $(\mathrm{BALB} / \mathrm{cJ} \times$ C57BL/6J)F2 mice. Learn Mem 5:391-403.

Vertes RP (2002) Analysis of projections from the medial prefrontal cortex to the thalamus in the rat, with emphasis on nucleus reuniens. J Comp Neurol 442:163-187.

Waddell J, Dunnett C, Falls WA (2004) C57BL/6J and DBA/2J mice differ in extinction and renewal of extinguished conditioned fear. Behav Brain Res 154:567-576.

Wahlsten D, Bachmanov A, Finn DA, Crabbe JC (2006) Stability of inbred mouse strain differences in behavior and brain size between laboratories and across decades. Proc Natl Acad Sci U S A 103:16364-16369.

Walker DL, Ressler KJ, Lu KT, Davis M (2002) Facilitation of conditioned fear extinction by systemic administration or intra-amygdala infusions of D-cycloserine as assessed with fear-potentiated startle in rats. J Neurosci 22:2343-2351.

Wang H, Ferguson GD, Pineda VV, Cundiff PE, Storm DR (2004) Overexpression of type- 1 adenylyl cyclase in mouse forebrain enhances recognition memory and LTP. Nat Neurosci 7:635-642.

Wehner JM, Radcliffe RA, Rosmann ST, Christensen SC, Rasmussen DL, Fulker DW, Wiles M (1997) Quantitative trait locus analysis of contextual fear conditioning in mice. Nat Genet 17:331-334.

Wellman CL, Izquierdo A, Garrett JE, Martin KP, Carroll J, Millstein R, Lesch KP, Murphy DL, Holmes A (2007) Impaired stress-coping and fear extinction and abnormal corticolimbic morphology in serotonin transporter knock-out mice. J Neurosci 27:684-691.

Yang RJ, Mozhui K, Karlsson RM, Cameron HA, Williams RW, Holmes A (2008) Variation in mouse basolateral amygdala volume is associated with differences in stress reactivity and fear learning. Neuropsychopharmacology, in press.

Zushida K, Sakurai M, Wada K, Sekiguchi M (2007) Facilitation of extinction learning for contextual fear memory by PEPA: a potentiator of AMPA receptors. J Neurosci 27:158-166. 